\title{
Pre-Columbian soil fertilization and current management maintain food resource availability in old-growth Amazonian forests
}

\author{
Carolina Levis $(\mathbb{D} \cdot$ Marielos Peña-Claros • Charles R. Clement • Flavia R. C. Costa • \\ Rubana Palhares Alves • Maria Julia Ferreira • Camila Guarim Figueiredo • Frans \\ Bongers
}

Received: 2 July 2019 / Accepted: 13 February 2020 /Published online: 14 March 2020

(C) The Author(s) 2020

\begin{abstract}
Aims The extent and persistence of pre-Columbian human legacies in old-growth Amazonian forests are still controversial, partly because modern societies reoccupied old settlements, challenging the distinction between pre- and post-Columbian legacies. Here, we compared the effects of pre-Columbian vs. recent landscape domestication processes on soils and vegetation in two Amazonian regions.
\end{abstract}

Responsible Editor: Lucy Rowland.

Electronic supplementary material The online version of this article (https://doi.org/10.1007/s11104-020-04461-z) contains supplementary material, which is available to authorized users.

C. Levis $(\bowtie) \cdot$ M. Peña-Claros $\cdot$ F. Bongers

Forest Ecology and Forest Management Group, Wageningen

University \& Research, Wageningen, The Netherlands

e-mail: carollevis@gmail.com

C. Levis - R. P. Alves

Programa de Pós-Graduação em Ecologia, Instituto Nacional de Pesquisas da Amazônia, Manaus, AM, Brazil

C. Levis

Programa de Pós-Graduação em Ecologia, Universidade Federal de Santa Catarina, Florianópolis, SC, Brazil

\section{R. Clement}

Coordenação de Tecnologia e Inovação, Instituto Nacional de Pesquisas da Amazônia, Manaus, AM, Brazil
Methods We studied forest landscapes at varying distances from pre-Columbian and current settlements inside protected areas occupied by traditional and indigenous peoples in the lower Tapajós and the upper-middle Madeira river basins. By conducting 69 free-listing interviews, participatory mappings, guided-tours, 27 forest inventories, and soil analysis, we assessed the influences of pre-Columbian and current activities in soils and plant resources surrounding the settlements.

\footnotetext{
F. R. C. Costa

Coordenação de Biodiversidade, Instituto Nacional de Pesquisas da Amazônia, Manaus, AM, Brazil

M. J. Ferreira

Programa de Pós-Graduação em Botânica, Instituto Nacional de Pesquisas da Amazônia, Manaus, AM, Brazil

M. J. Ferreira

Programa de Pós-Graduação em Etnobiologia e Conservação da Natureza, Universidade Federal Rural de Pernambuco, Recife, PE, Brazil

C. G. Figueiredo

Department of Anthropology, University of Toronto, Toronto, ON, Canada

C. G. Figueiredo

Norcan Consulting Ltda, Prince George, BC, Canada
} 
Results In both regions, we found that pre-Columbian villages were more densely distributed across the landscape than current villages. Soil nutrients (mainly $\mathrm{Ca}$ and $\mathrm{P}$ ) were higher closer to pre-Columbian villages but were generally not related to current villages, suggesting past soil fertilization. Soil charcoal was frequent in all forests, suggesting frequent fire events. The density of domesticated plants used for food increased in phosphorus enriched soils. In contrast, the density of plants used for construction decreased near current villages.

Conclusions We detected a significant effect of past soil fertilization on food resources over extensive areas, supporting the hypothesis that pre-Columbian landscape domestication left persistent marks on Amazonian landscapes. Our results suggest that a combination of preColumbian phosphorus fertilization with past and current management drives plant resource availability in old-growth forests.

Keywords Anthropogenic soils · Historical ecology Forest resources · Domesticated plants · Landscape domestication $\cdot$ Protected areas

\section{Introduction}

The extraordinary capacity of human societies to domesticate landscapes has promoted global alterations in natural ecological processes, ecosystems and species distributions (Boivin et al. 2016). Landscape domestication is defined as a continuum of land transformations by humans extending from semi-natural landscapes to cultivated lands and densely settled areas (Clement 1999; Ellis 2015; Clement and Cassino 2018) in which human manipulation of species populations and soil properties resulted in more secure and productive areas (Clement 1999; Erickson 2008). Evidence of landscape domestication has been found in extensive areas that - to the untrained eye - may seem natural (van Gemerden et al. 2003; Dambrine et al. 2007; Ross 2011; Levis et al. 2017). For instance, previous studies have shown that species richness and soil nutrients increase near ancient Roman settlements abandoned for millennia (Dambrine et al. 2007). Similarly, soil phosphorus and calcium are significantly higher in old habitation sites of the First Nations along the British Columbian Coast (Trant et al. 2016). In Mesoamerican forests, a higher abundance of plant species used by Maya people for daily needs persists in densely-settled forest areas even after centuries of human abandonment (Ross 2011). In southern Amazonia, a mosaic of domesticated landscapes was detected in an area of approximately $50,000 \mathrm{~km}^{2}$ in the Upper Xingu River basin (Heckenberger et al. 2008) and was recently estimated to occur in an area of approximately $400,000 \mathrm{~km}^{2}$ across the entire southern region (de Souza et al. 2018).

Since domestication involves the manipulation of species populations and ecosystem functioning for human welfare (Clement 1999), this process depends on both the energy invested in ecosystem transformation and cumulative cultural and material inheritances of a given society (Ellis 2015). Thus, it is not surprising that wide-ranging evidence of this process has been found across Amazonia (Clement et al. 2015). The most common signatures left by pre-Columbian peoples in densely settled areas are patches of Amazonian Dark Earth (ADE or Terra Preta de Índio - TPI) (Heckenberger and Neves 2009). These anthropogenic soils are rich in nutrients, ceramics, plant and animal remains, and charcoal. They were created by the accumulation and burning of domestic waste in habitation zones (Neves et al. 2003; Woods et al. 2013). Thus, ADE sites are considered pre-Columbian refuse heaps with high fertility. Anthropogenic dark-brown to brown soils are slightly richer in nutrients compared with adjacent soils, but they are generally less fertile than ADE. These brown soils often contain many pieces of charcoal, but few or no ceramics and occur in the surroundings of ADE, which suggests that they probably originated from past cultivation practices, such as mulching and burning of infield waste (Woods et al. 2013).

Charcoal records have also been used to identify ancient cultivated landscapes across Amazonia (Mayle and Power 2008; Mayle and Iriarte 2014), as fire was the main tool used by indigenous people to transform forest landscapes around their villages (Erickson 2008). Although fire regimes are often linked with past human disturbance (Mayle and Power 2008), caution is needed given that the length and severity of dry seasons was most likely associated with changes in precipitation regimes during the Holocene as well as with human activities (Maezumi et al. 2018b).

Signs of landscape domestication can also be detected by assessing the distribution and abundance of useful, managed and/or domesticated species (Clement and Cassino 2018), as observed in Central Amazonia (Levis et al. 2012; Ferreira et al. 2019), Western Amazonia (Franco-Moraes et al. 2019) and across the Amazon 
basin (Levis et al. 2017). At least 85 arboreal species, mostly used for food, have populations domesticated to some degree by pre-Columbian peoples in Amazonia (Levis et al. 2017), and they are concentrated in and around settlements due to numerous historical management practices (Levis et al. 2018). Thus, landscapes around human settlements can be analysed as a durable record of the activities practiced by human societies (Balée 2006).

The persistence of domestication processes beyond densely settled areas is, however, still controversial for several reasons. First, ecological and archaeological studies have mostly investigated human impacts only along the margins of major Amazonian rivers in areas expected to have been heavily modified (McMichael et al. 2017b). Second, scholars are using different methods, proxies and datasets in different localities, but each method detects specific legacies of human activities and their results may seem contradictory (Piperno et al. 2015, Stahl 2015). Third, the effects of pre-Columbian activities on forests could have disappeared after their abandonment due to natural processes (Bush et al. 2015; McMichael et al. 2017a), since many old settlements were abandoned and hidden by forest regrowth for centuries (Denevan 1992). Fourth, and equally important, modern indigenous societies often decide to settle in archaeological sites or places they had occupied before (Rival 2007; Politis 2009), making the distinction between pre-Columbian and postconquest management practices particularly challenging (McMichael et al. 2017a, but also see Junqueira et al. 2017).

One question that remains open is whether preColumbian landscape domestication persisted in oldgrowth forests over time or whether legacies of past domestication processes are a result of recent management practices. Here we compared pre-Columbian vs. recent human influences on forest landscapes surrounding past and current villages. To disentangle their effects, we first mapped all pre-Columbian villages (ADE sites) and current villages known by local people in the study areas, and then we randomly sampled 27 forest plots across distance gradients from these villages. Because past and current Amazonian people often use forests for hunting and gathering more intensively near their villages, human intervention in the landscape is expected to decrease with increasing distance from villages (Heckenberger et al. 2008). By sampling forests at different distances to pre-Columbian and current villages, we assessed their relative influences in forest soils and plant resources. Because anthropogenic soils (ADE and dark brown to brown soils) were created extensively in pre-Columbian times, we expected to find higher levels of soil fertility in old-growth forests closer to pre-Columbian villages than to current villages. However, since ecological knowledge is continuously transmitted between human generations inside and outside their territories over time (Balée 2000; Cámara-Leret et al. 2019), we expected a cumulative effect of past and current management on the availability of useful and domesticated plants for local people within these forests.

\section{Materials and methods}

Ethical procedures and authorizations

Following Brazilian law and local rules, all authorizations to conduct the study were obtained before field work. The study was approved by the Brazilian Ethics Committee for Research with Human Beings (Process $\mathrm{n}^{\circ} 10,926,212.6 .3001 .5020$ and $\left.\mathrm{n}^{\circ} 1.396 .762 / 2016\right)$, the Regional Coordinator of the Brazilian National Indigenous Foundation (FUNAI - CR Madeira, $n^{\circ}$ 001/APIJ/ 2016), the Brazilian System of Protected Areas (SISBIO, process $n^{\circ} 47,373-1,45,094-1$ and 53,0412), and National Institute of Historic and Artistic Heritage (01494.000171/2011-78). In each village, the local or indigenous leadership approved the study and all informants signed free informed consent terms when they participated in our activities.

Study sites and their long-term human history

To expand the comparison between pre-Columbian and modern societies, we studied the landscape around six villages inside three distinct protected areas - one Indigenous Land and two National Forests inhabited by traditional societies - located in the upper-middle Madeira River (Jiahui Indigenous Land and Humaitá National Forest - FLONA Humaitá) and the lower Tapajós River (Tapajós National Forest - FLONA Tapajós; Fig. 1). The villages were chosen because their residents agreed to participate in our study and they knew about the location of ADE sites around the villages. Environmental conditions vary between these two river basins. A minimum of three dry months occur along the middle-upper 


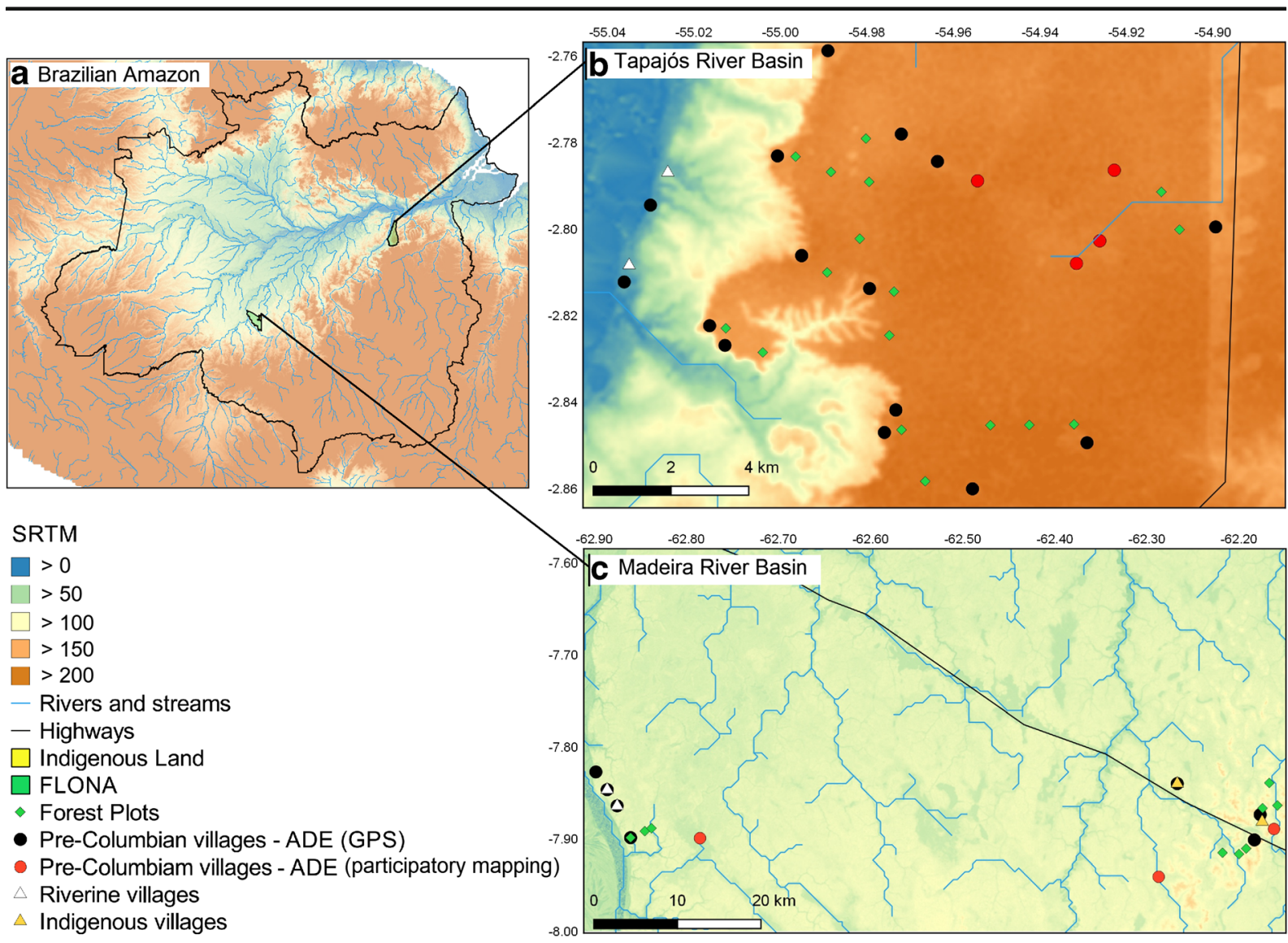

Fig. 1 a) The location of the protected areas studied in the Brazilian Amazon, b) the Tapajós National Forest in the lower Tapajós River basin, and c) the Humaitá National Forest and Jiahui Indigenous Land in the upper-middle Madeira River basin. PreColumbian villages were sedentary settlements with anthropogenic soils (ADE sites). The approximate location of some ADE sites were obtained with participatory mapping and complemented with

Madeira and five dry months along the lower Tapajós (Kummerow et al. 1998). Altitude also varies between forest plots in the Madeira River basin (80-110 m) and in the Tapajós River basin (150-200 m) (Fig. 1a).

Four of six villages - two in the FLONA Tapajós and two in the FLONA Humaita - are inhabited by traditional societies, and two villages are in the Jiahui Indigenous Land. Traditional societies have existed for at least 100 years; most of them are descendants of migrants who intermarried with local indigenous peoples, but they are not members of an indigenous group. Inhabitants of Jiahui Indigenous Land are members of the Jiahui indigenous group that speak a Tupi-Guarani language (Peggion 2006). Traditional societies and the Jiahui indigenous group regularly practice farming, fishing, hunting, timber and non-timber forest product extraction, and, the information collected during guided tours. With guided tours we validated the location of most ADE sites. Some sites near the Tapajós were mapped by Schaan et al. (2015). Altitude varies among forest plots in the Madeira River basin (80-110 m) and in the Tapajós River basin (150-200 m), and this variation was detected using SRTM (Shuttle Radar Topography Mission) images available at http:/www.dsr.inpe.br/topodata/

in the case of the FLONA Tapajós, the villages are also involved in community-based tourism. In this study, we defined current villages as the areas currently inhabited (most were established approximately 120 years ago) and pre-Columbian villages as the sites with $\mathrm{ADE}$, which are likely older than 350 years (de Souza et al. 2019).

Although all archaeological sites mapped in both regions contain $\mathrm{ADE}$ sites with ceramics, which indicate sedentary pre-Columbian occupation (Neves et al. 2003), the ancient histories of the regions differ. Archaeological sites of the lower Tapajós River basin are mainly associated with the Tapajó or Santarém pottery, which is affiliated with the Incised and Punctate tradition (Stenborg 2016; Figueiredo 2019), while many sites in the middle-upper Madeira River basin are multi-componential, with the most recent layer containing the 
Polychrome pottery tradition (Moraes and Neves 2012; Barreto et al. 2016). Before this study, 148 archaeological sites had been recorded in the lower Tapajós River basin, in an area of $10,000 \mathrm{~km}^{2}$, including 13 sites inside the FLONA Tapajós (e.g., Schaan et al. 2015; Stenborg, 2016; Stenborg et al. 2018; Figueiredo 2019). Almost $70 \%$ of these archaeological sites are located on the interfluve (away from major Amazonian rivers), $6 \%$ are located on hillsides, and only $24 \%$ are located along the Tapajós River, secondary rivers and lakes (Stenborg et al. 2018). Despite the abundance of archaeological sites in interfluvial areas, riverside settings have a longer occupation history, likely starting about 4300 cal BP (calibrated years Before Present) (Maezumi et al. 2018a). Pre-Columbian activities intensified around 1250 cal BP and remained until European conquest and subsequent colonization (500 cal BP, Maezumi et al. 2018a). In contrast to the lower Tapajós River region, archaeological sites of the upper-middle Madeira River near Humaitá were poorly described and few sites were mapped before this study. However, the occupation of the upper Madeira River basin is much older than of the lower Tapajós, starting around 12,000 BP (Miller 1992) and intensified around 1000 BP when the Polychrome pottery tradition expanded along the Madeira (Moraes and Neves 2012). The expansion of this tradition has been likely associated with the expansion of Tupi speaking groups (Barreto et al. 2016).

Management practices probably intensified when human populations expanded around a thousand years ago in both river basins (Levis et al. 2018). After European conquest, indigenous populations collapsed and a new wave of human expansion occurred during the rubber boom (in the late nineteenth century), when both the Tapajós and Madeira basins were occupied by their current inhabitants. Management activities that occurred during this period may also have influenced forest structure and composition, since local people mentioned that at that time they used forests more extensively than they do today. In the last century, people have favoured the development of rubber agroforests by actively planting rubber trees (Hevea brasiliensis) in their manioc fields and managing them in fallows that became agroforests (Schroth et al. 2003).

Ethnoecological and archaeological methods

In each village we conducted the following activities: (1) free listing interviews with 33 key informants in the
FLONA Tapajós, 24 in the FLONA Humaitá and 12 in the Jiahui Indigenous Land about which trees and palms are useful for them, their types of uses, and the forest management activities related to these plants; (2) participatory mapping and guided tours along $80 \mathrm{~km}$ of trails in the Tapajós with the seven most experienced informants and approximately $115 \mathrm{~km}$ of trails in the Madeira with the 15 most experienced informants to describe the extension of their activities in the forest and the location of currently unoccupied ADE sites, and to identify the plants they currently manage in the forest; and (3) 27 forest inventory plots randomly placed at different distances from current and pre-Columbian villages. We used snowball sampling techniques to find informants who know and use forest species (Albuquerque et al. 2014), and collected the GPS points of all ADE sites and of useful plants cited in the interviews. In total we interviewed 24 men and 9 women in the Flona Tapajós, whose ages varied from 25 to 83 years; 20 men and 4 women in the Flona Humaitá, whose ages varied from 19 to 68 years; and 10 men and 2 women in the Jiahui Indigenous Land, whose ages varied from 18 to 85 years. For more details about these ethnoecological methods see Cassino et al. (2019).

Based on local knowledge and previous study (Levis et al. 2017), we created four categories of useful plants. Useful plants were defined as species that have been used for any reason in the past or are currently used by local people. First, we classified all useful plants into two categories: 1) useful plants that are not managed; and 2) useful plants that are managed today (see Levis et al. 2018 for more details about the management categories). Within the currently managed plants, we categorized a third group of plants that are more intensively managed, because people occasionally plant them in cultivated landscapes, here called cultivated plants. Because plant domestication is long-term process that is difficult to detect using only local interviews, we used the literature to determine which species have populations with some degree of domestication reported somewhere in Amazonia (Levis et al. 2017) and created a fourth category of useful plants, namely domesticated plants. As we wanted to compare pre-Columbian and post-Columbian impacts on forest resources, our analyses focused on useful and domesticated plants.

Inside the FLONA Tapajós, the extension of the preColumbian villages (ADE) in most of the sites was measured with the assistance of a member of the community and handheld GPS. In addition, in two ADE 
sites, shovel test pits supervised by an archaeologist (coauthor CGF) were excavated in two transects to delimit their extension. Handheld GPS and Google Earth images were also used to map the area occupied by current houses and homegardens in the villages we worked with (Maguarí and Jamaraquá). In the Madeira basin, we could not measure the size of the ADE sites because of logistical limitations.

We also calculated the density of pre-Columbian and current villages that occur in the study area in both basins and the distance from these villages to major rivers, perennial rivers and streams. We used all rivers of the HydroSHEDS dataset to define streams and "upcell" values greater than 15,000 to define perennial rivers of approximately $10 \mathrm{~m}$ width, following the study of McMichael et al. (2014). We estimated study area in both basins based on the extension of the local people's activities in the forest described during participatory mapping and guided-tours: 12,400 ha in the Flona Tapajós; 15,800 ha in the Flona Humaitá; 25,600 ha in the Jiahui Land.

\section{Forest inventories}

We randomly sampled forest plots of 0.5 ha $(50 \times$ $100 \mathrm{~m})$ at different distances from pre-Columbian $(0$ $4.1 \mathrm{~km})$ and current villages $(0.9-15.4 \mathrm{~km})$. Plots were restricted to old-growth forest on terra-firme terrain located on plateaus in both basins (Fig. 1b-c). We did not sample forests located more than $4 \mathrm{~km}$ from preColumbian sites, because the mean distance we found between pairs of sites in the Madeira study area is $5 \mathrm{~km}$ and in the Tapajós study area is $2 \mathrm{~km}$. To sample the plots at different distances from pre-Columbian villages, we created buffers around the ADE sites, differing in size $(0-1,1-2,2-4 \mathrm{~km})$, based on land use zones described in a previous study (Heckenberger et al. 2008). We used these buffer classes to randomly sample one location for our inventory plot per pre-Columbian village per buffer zone. We selected a location for the plot where the buffers did not overlap more than $50 \%$ with a neighbouring buffer class. Distances and buffers were established based on the information of ADE sites gathered from participatory mapping and with GPS during guided tours, and were mapped with QGIS 2.18.25 software.

During the plot inventories, trees and palms with diameters at breast height $(\mathrm{dbh}) \geq 1 \mathrm{~cm}$ were sampled in sub-plots of 0.01 ha, trees and palms with $\mathrm{dbh} \geq$
$10 \mathrm{~cm}$ were sampled in sub-plots of 0.25 ha, and trees and palms with $\mathrm{dbh} \geq 30 \mathrm{~cm}$ were sampled in the full 0.5 ha plot. We counted and measured the diameter of all living trees and palms present in the plot, but we only identified and collected botanical vouchers for useful species with vernacular names listed in the interviews. Botanical identification was based on the Species List of the Flora do Brazil available at http://www. floradobrasil.jbrj.gov.br. The vouchers were deposited at the INPA Herbarium, the UFOPA Herbarium, and the EAFM Herbarium. For the analysis, we used the vernacular names given by informants because these are the units that people actually use and manage. Some vernacular names refer to single botanical species, but others refer to a group of botanical species that share similar traits, and which often belong to the same botanical genus or family (Berlin 1992).

Soil data

To detect human effects on forest soils and to identify fire events, we used a post-hole digger to collect soils and pieces of charcoal in three locations along the central plot line from 0 to $40 \mathrm{~cm}$ depth. Sample points cover a gradient from dark soils and dark-brown soils to yellow-brown soils. Pieces of charcoal visible to the naked eye were quantified every $10 \mathrm{~cm}$ of the 0 to $40 \mathrm{~cm}$ samples done in each of the three locations per plot; frequency of charcoal was calculated by the presence/absence of these pieces in each point at each depth, so $100 \%$ frequency is charcoal presence at all 12 points/depths per plot. We also measured the frequency of soil charcoal below $20 \mathrm{~cm}$ and above $20 \mathrm{~cm}$ and found that the frequencies of charcoal in these two soil layers were highly correlated (Spearman's rank correlation $=0.71, p<0.001$ ). Due to lack of funding we could not date the charcoal found in our samples, but as suggested in the literature we assumed that charcoal above $20 \mathrm{~cm}$ is more likely to be associated with modern fires and below this layer is more likely to be associated with pre-Columbian fires (McMichael et al. 2012). ADE sites in the Flona Tapajós were dated between 3362 and 3160 cal BP to $666-622$ and $612-559$ cal BP (Figueiredo 2019), and 530-450 cal BP (Maezumi et al. 2018a). Also, ADE sites across Amazonia are likely older than 350 years BP according to the literature review of de Souza et al. (2019).

Only soil samples from 0 to $30 \mathrm{~cm}$ depth were dried and analysed in the Plant and Soil Thematic Laboratory 
at INPA for chemical and physical properties. Total phosphorus was determined by acid digestion using concentrated sulphuric acid (Quesada et al. 2010) and available phosphorus was determined by Mehlich I Teixeira et al. (2017). Exchangeable $\mathrm{Ca}, \mathrm{Mg}, \mathrm{K}, \mathrm{Na}$ and $\mathrm{Al}$ were determined by the silver thiourea method (Pleysier and Juo 1980). Organic carbon was determined by Walkley and Black (1934), and pH was analysed in water at 1: $2.5 \mathrm{ml}$. The percentage of sand, silt and clay was also calculated following (Teixeira et al. 2017).

Data analysis

All statistical analyses were performed in the R platform (3.5.1, R Development Core Team 2018). To evaluate if pre-Columbian and current villages were equally distributed along major rivers, perennial rivers and streams, we measured the minimum linear distances between villages and from villages to all river types using the "NNJoin" tool of QGIS version 2.18.25. As proxies for the intensity of human activities in forest plots, we measured the walking distance from forest plots to the current villages (in kilometers - $\mathrm{km}$ ) and the linear distance from forest plots to pre-Columbian villages $(\mathrm{km})$, because we don't know where pre-Columbian pathways were located.

We explored the variability of soil chemical and physical variables across forest plots using Principal Component Analysis (PCA) based on a correlation matrix. Soil variables with skewed distributions (total $\mathrm{P}$, available $\mathrm{P}, \mathrm{Ca}, \mathrm{Mg})$ were $\log$-transformed $\left(\log _{10}+1\right)$. We included only the percentage of clay and sand in the PCA, because texture variables sum to $100 \%$, which means they are complementary. The PCA was used to evaluate the spatial distribution of soil properties and help identify the soil variables that are most associated with the variation in soil fertility.

To understand how pre-Columbian and current human activities have influenced forest soils, forest structure and forest resources we used structural equation modelling (SEM). SEM is based on multiple regression equations, and can be used to test indirect and direct effects and investigate causality between variables (Grace et al. 2010). To do so, we defined a priori SEM models including the direct and indirect effects of human activities and edaphic factors on forest structure and forest resource variables (Fig. S1), and the models were adjusted if necessary (Grace et al. 2010).
Correlations among factors are considered and reported when significant correlations are detected. Because we defined models a priori in SEM, the models are considered to be statistically accepted when they cannot be rejected $(p>0.05)$, meaning that the proposed relationships accurately describe the data. We ran separate models to understand how forest structure variables (stand basal area, density of canopy stems and density of sub-canopy stems) and forest resource variables (relative basal area and relative density of useful and domesticated plants used for food and construction) are related to the four fixed predictor variables: distance from plots to pre-Columbian villages, distance from plots to current villages, soil phosphorus, and soil charcoal $(0-40 \mathrm{~cm})$ (Fig. S1). The sum of all stems with $\mathrm{dbh} \geq 1 \mathrm{~cm}$ was calculated to define the density of subcanopy stems in 1 ha and the sum of all stems with $\mathrm{dbh} \geq 10 \mathrm{~cm}$ was calculated to define the density of canopy stems in 1 ha. The stand basal area (BA) is the sum of the basal area of all stems with $\mathrm{dbh} \geq 10 \mathrm{~cm}$ in 1 ha because sub-canopy stems make a small contribution to BA. Basin (Tapajós and Madeira) was incorporated as a random factor in all models; because samples within the same region share similar characteristics as they share similar environments and we wanted to account for the spatial aggregation of our data within basins.

Structural equation models were created using mixed-linear models, which were evaluated using the "Ime" function of the "nlme" package (Pinheiro et al. 2018) and performed using the "psem" function of the piecewise SEM package (Lefcheck 2016). The PCA analysis was run using the "prcomp" function and visualized using the "autoplot" function of the "ggfortify" package (Tang et al. 2016). Conditional plots were used to visualize the mixed-effect models using the "visreg" package (Breheny and Burchett 2017).

\section{Results}

Spatial patterns of pre-Columbian and modern human occupations

Pre-Columbian villages were smaller in estimated size, but more densely distributed across the landscapes (Table 1). The total area occupied by 12 preColumbian villages in the FLONA Tapajós is approximately 93 ha (mean size $=8$ ha) out of our study area of 
12,400 ha, while the estimated area occupied by houses and homegardens of the two current riverside villages is approximately 46 ha of 12,400 ha. In the FLONA Tapajós, the two current villages are located along the Tapajós River banks with a density of 0.02 villages $/ \mathrm{km}^{2}$ in the study area, whereas 19 pre-Columbian villages were spread across the study area with a density of 0.15 villages $/ \mathrm{km}^{2}$, with some pre-Columbian villages located up to $15 \mathrm{~km}$ from this river's margin (Fig. 1; Table 1). In the Madeira River basin, pre-Columbian and current villages were found along this river's banks in the FLONA Humaitá and approximately $70 \mathrm{~km}$ from this river's margin in the Jiahui Indigenous Land. The total amount of the study area in the Flona Humaitá was 15,800 ha and the Jiahui Indigenous Land was 25,600 ha. In the FLONA Humaitá, the density of the current villages was $0.01 / \mathrm{km}^{2}$, whereas the density of pre-Columbian villages was 0.03 villages $/ \mathrm{km}^{2}$. In the Jiahui Indigenous Land, the density of current villages was 0.01 villages $/ \mathrm{km}^{2}$, whereas the density of preColumbian was 0.02 villages $/ \mathrm{km}^{2}$. Although the density of pre-Columbian villages in the Tapajós is much higher than the density of villages in Madeira, we detected similar densities along these rivers' banks and in areas distant from major and perennial rivers $(70$ and $20 \mathrm{~km}$, respectively), but near small streams.

Forest resources around pre-Columbian and modern human occupations

Based only on local knowledge, in the Tapajós villages we identified 193 useful plants, of which 140 were cited by the informants as managed, and of these 52 are occasionally cultivated. In the Madeira villages, we identified 167 useful plants, of which 126 are managed, and of these 49 are occasionally cultivated. Based on the list of domesticated species of Levis et al. (2017), we found that $13 \%$ of the 193 useful plants in the Tapajós and $14 \%$ of the 167 useful plants in the Madeira were domesticated by pre-Columbian people somewhere in Amazonia (i.e., not necessarily in the lower Tapajós or upper-middle Madeira).

Twenty useful plant species dominate half of the basal area across forest plots in both regions and at least a quarter of the total density of individuals (for more details of dominant species see Table S1). In both regions, current people have managed at least 15 of the 20 dominant useful species and pre-Columbian peoples likely domesticated four of them. Caryocar villosum,
Dipteryx odorata, Hymenea courbaril, Bertholletia excelsa were the four dominant domesticated species found in the Tapajós plots, and B. excelsa, C. villosum, Theobroma subincanum, Caryocar glabrum were the dominants found in the Madeira plots. Thus, the structure of these forests around human occupations is mostly driven by these 20 dominant species, managed for food and construction materials, and sometimes domesticated for food.

Soil patterns within and across basins

Soil texture differs between our study sites in the Tapajós and Madeira basins (Table 2). The first axis of the PCA (PC1) explained $32.9 \%$ of the variation in soil data and separated plots with high concentrations of clay and organic matter in the Tapajós basin from plots with higher concentrations of sand in the Madeira basin (Fig. S2 and S3). The PC1 was highly correlated with clay and sand, and represents a gradient of soil texture. The second axis of the PCA (PC2) explained $31.1 \%$ of the variation in soil data and represents a gradient of soil fertility, separating plots with higher $\mathrm{pH}$ and nutrient contents $(\mathrm{Ca}, \mathrm{P}, \mathrm{Mg})$ from plots with lower values of these variables. The forest plot sampled over an ADE site had a considerably higher value of soil nutrients, such as $\mathrm{P}, \mathrm{Ca}, \mathrm{Mg}$, and $\mathrm{pH}$, than all other plots. Three forest plots in the Madeira basin are located on Plinthosols, while the other plots in the Madeira basin and all plots in the Tapajós basin are located on Ferrasols; for more details of differences in soil variables in each basin, see Table 2).

We found that pre-Columbian human activities are associated with an increase in soil fertility (Fig. 2). Ca, total $\mathrm{P}$, and the scores of the soil fertility axis (PC2) were higher in forest soils closer to pre-Columbian villages and significantly decreased with distance from forest plots to these villages (Fig. 2a, c and g, $p=0.002$, $p<0.001$ and $p=0.015$, respectively). However, most soil variables were not related to the distance to current villages (Fig. 2d, f and h), except for Ca that increased slightly with distance from plots to current villages (Fig. 2b, $p=0.048$ ).

Given the strong association of total phosphorus to the soil fertility axis (Table 2) and given that total soil phosphorus was previously recognized as the best indicator of anthropogenic enrichment of ADE sites (Alho et al. 2019), total $P$ was chosen to represent soil fertility in our structural equation models. Additionally, together 
Table 1 Distribution of current and pre-Columbian villages, rivers and streams in the two study areas. Major rivers are the Tapajós and Madeira rivers.

\begin{tabular}{|c|c|c|c|c|c|c|c|}
\hline Basin & $\begin{array}{l}\text { Location of } \\
\text { villages }\end{array}$ & $\begin{array}{l}\text { Number } \\
\text { of } \\
\text { villages }\end{array}$ & $\begin{array}{l}\text { Density of } \\
\text { villages / } \\
\text { km }^{2}\end{array}$ & $\begin{array}{l}\text { Distance } \\
\text { between } \\
\text { villages }(\mathbf{k m})\end{array}$ & $\begin{array}{l}\text { Distance from } \\
\text { villages to major } \\
\text { rivers }(\mathrm{km})\end{array}$ & $\begin{array}{l}\text { Distance from villages } \\
\text { to perennial rivers } \\
(\mathrm{km})\end{array}$ & $\begin{array}{l}\text { Distance from } \\
\text { villages to } \\
\text { streams (km) }\end{array}$ \\
\hline \multirow[t]{3}{*}{ Tapajós } & \multicolumn{7}{|c|}{ FLONA Tapajós } \\
\hline & Pre-Columbian & 19 & 0.15 & $2 \pm 1$ & $6 \pm 4$ & $6 \pm 4$ & $3 \pm 2$ \\
\hline & Current & 2 & 0.02 & 1 & 0 & NA & NA \\
\hline \multirow{3}{*}{ Madeira } & \multicolumn{7}{|c|}{ Jiahui Indigenous Land } \\
\hline & Pre-Columbian & 5 & 0.02 & $5 \pm 3$ & $70 \pm 4$ & $22 \pm 6$ & $1 \pm 1$ \\
\hline & Current & 2 & 0.01 & 11 & 65 and 76 & 27 and 16 & 1 and 2 \\
\hline \multirow{3}{*}{ Madeira } & \multicolumn{7}{|c|}{ FLONA Humaitá } \\
\hline & Pre-Columbian & 5 & 0.03 & $5 \pm 2$ & 0 & NA & NA \\
\hline & Current & 2 & 0.01 & 1 & 0 & NA & NA \\
\hline
\end{tabular}

Distance data presented are averages with one standard deviation. NA means not applicable. In the FLONA Tapajós, the total sizes of 12 preColumbian (92 ha) and two current villages (46 ha) were measured, but this was not possible in the FLONA Humaitá or Jiahui Land

Table 2 Mean, median, minimum and maximum values for each explanatory variable are presented per basin (Tapajós and Madeira).

\begin{tabular}{|c|c|c|c|c|c|c|c|c|c|c|}
\hline \multirow[t]{2}{*}{ Basin } & \multicolumn{4}{|c|}{ Tapajós } & \multicolumn{4}{|c|}{ Madeira } & \multicolumn{2}{|l|}{ PCA } \\
\hline & mean & median & $\max$ & $\min$ & mean & median & $\max$ & $\min$ & axis 1 & axis 2 \\
\hline \multicolumn{11}{|l|}{ Soil variables } \\
\hline Percentage of silt (\%) & 16 & 16 & 21 & 13 & 24 & 19 & 49 & 7 & - & - \\
\hline Percentage of clay $(\%)$ & 81 & 80 & 85 & 77 & 28 & 27 & 48 & 12 & $-0.90 * *$ & $-0.55^{*}$ \\
\hline Percentage of sand (\%) & 3 & 3 & 5 & 2 & 48 & 38 & 81 & 25 & $0.94 * *$ & 0.48 \\
\hline Organic Matter (g/kg) & 46.5 & 46.3 & 72.2 & 29.4 & 29.7 & 28.8 & 43.7 & 17.8 & $-0.8 * *$ & $-0.65^{*}$ \\
\hline Available Phosphorus (P, mg/kg) & 5.4 & 5.2 & 10.0 & 3.8 & 9.5 & 1.5 & 73.8 & 1.0 & $-0.84 * *$ & 0.37 \\
\hline Total Phosphorus (P, mg/kg) & 207.1 & 210.2 & 229.5 & 166.9 & 275.6 & 189.9 & 972.2 & 132.2 & -0.47 & $0.77 * *$ \\
\hline Calcium $(\mathrm{Ca}, \mathrm{cmol} / \mathrm{kg})$ & 0.161 & 0.053 & 1.006 & 0.016 & 0.479 & 0.057 & 3.752 & 0.015 & -0.25 & $0.90 * *$ \\
\hline Magnesium (Mg, cmol/kg) & 0.135 & 0.119 & 0.244 & 0.059 & 0.105 & 0.072 & 0.263 & 0.040 & -0.46 & $0.72 *$ \\
\hline Potassium $(\mathrm{K}, \mathrm{cmol} / \mathrm{kg})$ & 0.048 & 0.049 & 0.068 & 0.032 & 0.060 & 0.059 & 0.086 & 0.031 & $0.85 * *$ & 0.27 \\
\hline Sodium $(\mathrm{Na}, \mathrm{cmol} / \mathrm{kg})$ & 0.026 & 0.026 & 0.043 & 0.010 & 0.010 & 0.010 & 0.016 & 0.004 & $-0.85 * *$ & -0.53 \\
\hline Aluminium (Al, cmol/kg) & 0.523 & 0.470 & 1.154 & 0.172 & 0.488 & 0.499 & 0.846 & 0.142 & -0.26 & -0.01 \\
\hline $\mathrm{pH}\left(\mathrm{H}_{2} \mathrm{O}\right)$ & 4.7 & 4.7 & 5.1 & 4.3 & 4.8 & 4.6 & 5.4 & 4.4 & 0.11 & $0.92 * *$ \\
\hline Explained variation by PCA (\%) & & & & & & & & & 32.94 & 31.07 \\
\hline \multicolumn{11}{|l|}{ Soil charcoal frequency } \\
\hline $\begin{array}{l}\text { Percentage of charcoal } \\
(0-40 \mathrm{~cm})\end{array}$ & 81 & 83 & 100 & 27 & 49 & 47 & 73 & 27 & - & - \\
\hline \multicolumn{11}{|l|}{ Distance to human occupations } \\
\hline Distance to pre-Columbian villages (km) & 1.0 & 1.0 & 1.7 & 0.4 & 2.2 & 2.3 & 4.1 & 0.0 & - & - \\
\hline Distance to current villages $(\mathrm{km})$ & 9.0 & 7.4 & 15.4 & 3.3 & 6.0 & 5.5 & 10.4 & 0.9 & - & - \\
\hline
\end{tabular}

Significance levels are based on a Pearson correlation between soil variables and PCA axes ( $p$ values: $\leq 0.01$ '**’; $\leq 0.05$ '*’). Total phosphorus, available phosphorus, calcium and magnesium were $\log$-transformed $(\log 10(\mathrm{x}+1))$ for the PCA analysis 
a)

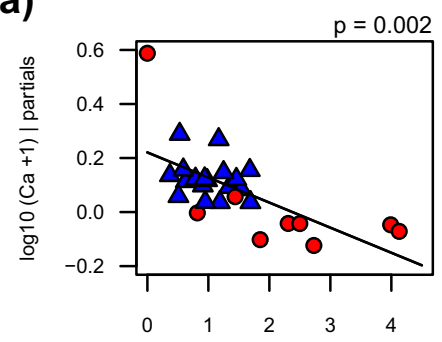

Distance to pre-Columbian villages $(\mathrm{km}) \mid$ partials

c)

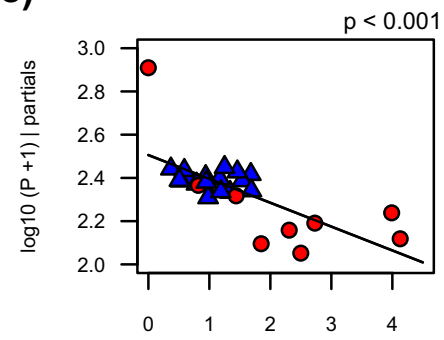

Distance to pre-Columbian villages $(\mathrm{km}) \mid$ partials

e)

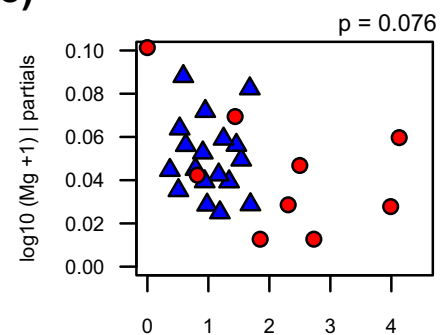

g)

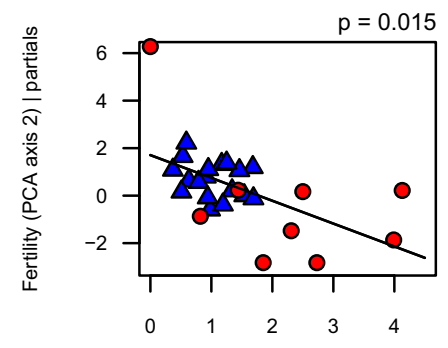

Distance to pre-Columbian villages $(\mathrm{km}) \mid$ partials

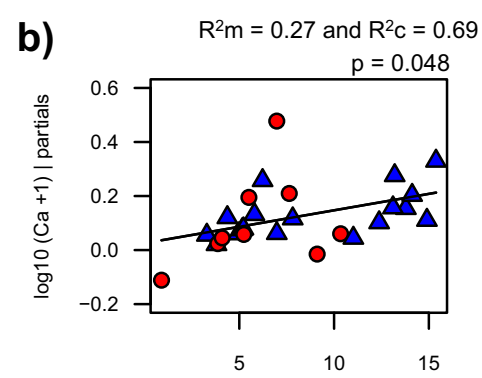

Distance to current villages | partials

d)

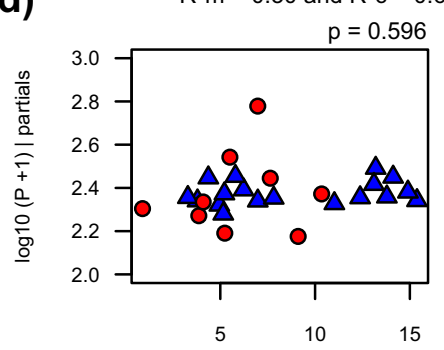

Distance to current villages $(\mathrm{km}) \mid$ partials

f)

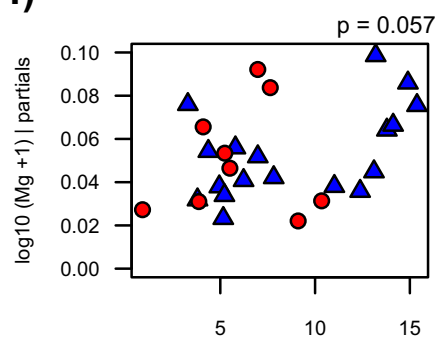

Distance to current villages | partials

h)

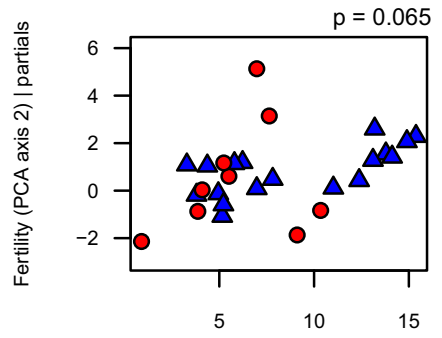

Distance to current villages | partials
Fig. 2 Effects of the distance from plots to pre-Columbian villages and the distance from plots to current villages on soil calcium $(\mathbf{a}, \mathbf{b})$, total phosphorus (c, d), magnesium $(\mathbf{e}, \mathbf{f})$ and the second axis of the PCA that represents the soil fertility gradient $(\mathbf{g}, \mathbf{h})$. Triangles are forest plots in the Tapajós River basin (18 plots) and dots are forest plots in the Madeira River basin ( 9 plots). Regression plots were obtained from mixed-models and the fitted line indicates significant fixed-effects detailed in Table S2: lme (soil variable $\sim$ distance to pre-Columbian villages + distance to current villages $+(1 \mid$ Basin $))$. Significance probabilities ( $p$ values) are shown and $\mathrm{R}^{2}$, $\mathrm{s}$ are given to indicate the total variation in a dependent variable that is explained by the combined fixed variables $\left(\mathrm{R}^{2}\right.$ marginal) and together with the random factor $\left(\mathrm{R}^{2}\right.$ conditional). Calcium, total phosphorus and magnesium were log-transformed $\left(\log _{10}+1\right)$ 

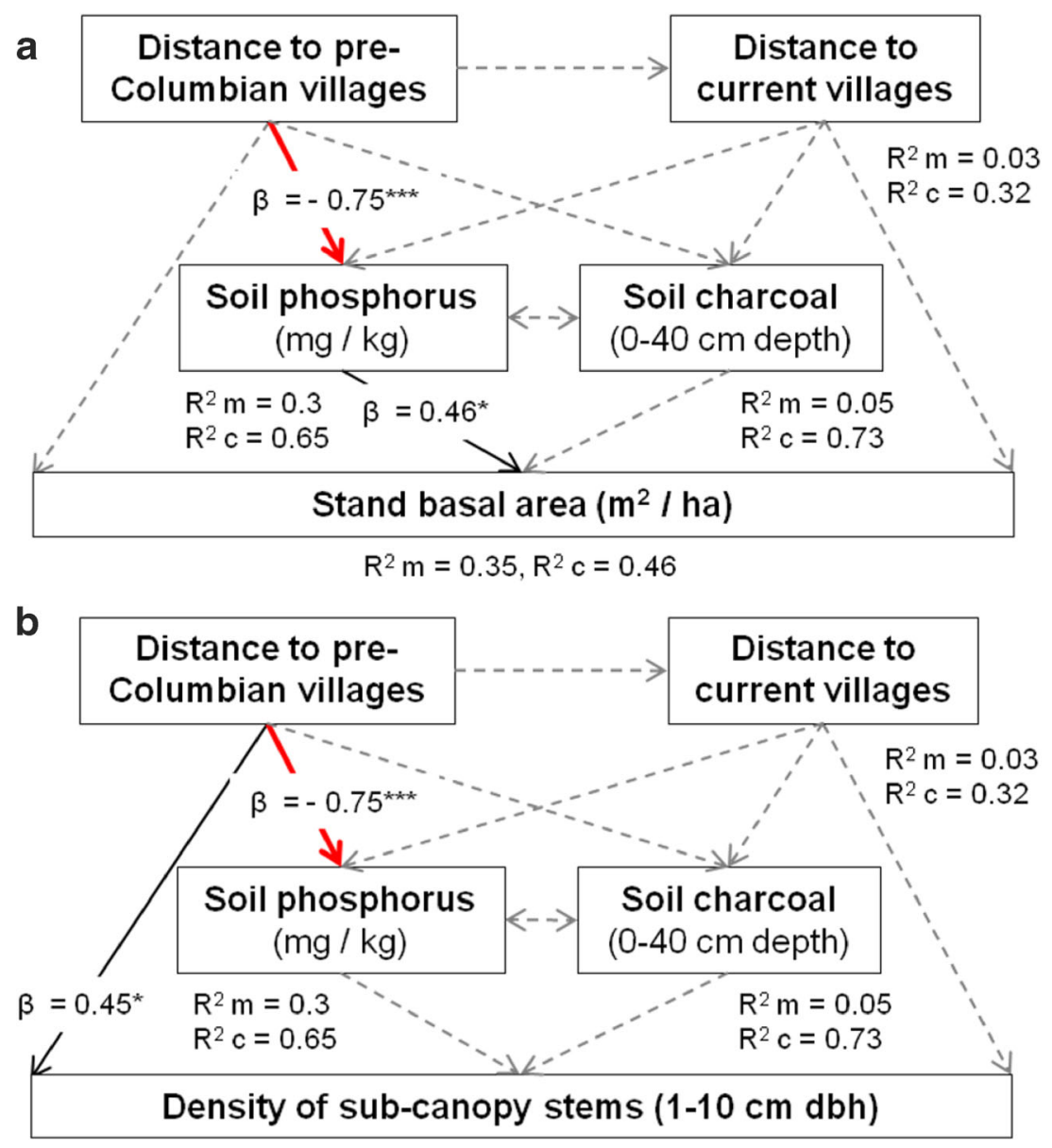

$$
R^{2} m=0.39, R^{2} c=0.44
$$

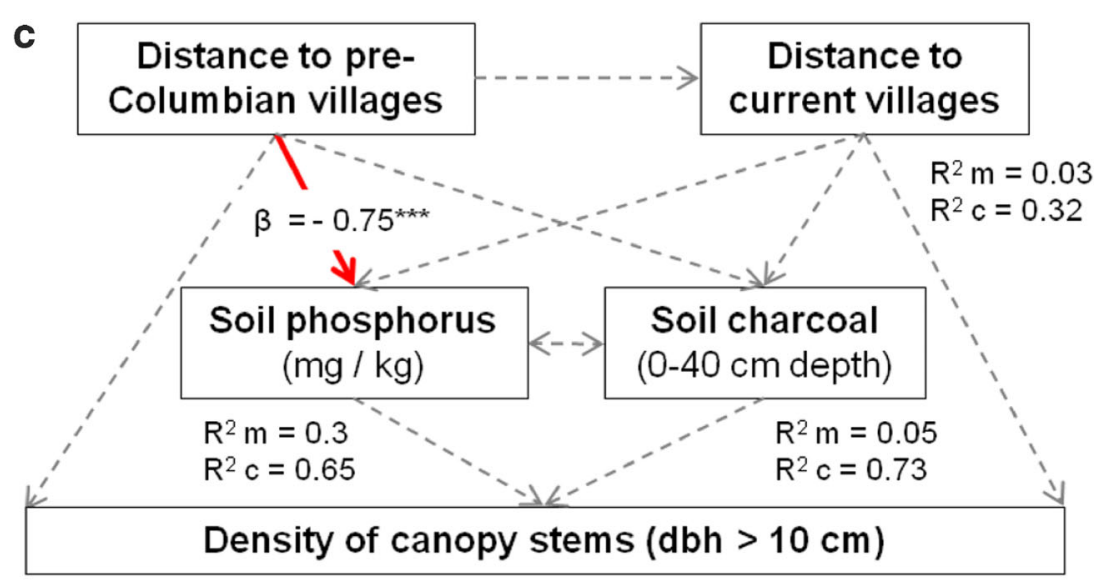

$$
\mathrm{R}^{2} \mathrm{~m}=0.08, \mathrm{R}^{2} \mathrm{c}=0.08
$$

Fig. 3 The structural equation models that show the direct and indirect effects of distance to pre-Columbian and current villages on a) stand basal area, b) density of sub-canopy stems, and c) density of canopy stems. Black continuous arrows show significant pathways, grey dotted arrows show non-significant pathways, and double-sided arrows show correlations. The standardized regression coefficient $(\beta)$ and significance probabilities $(p$ values: $\leq$

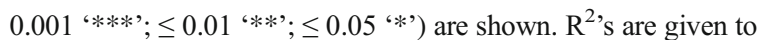
indicate the total variation in a dependent variable that is explained by the combined fixed variables $\left(\mathrm{R}^{2}\right.$ marginal) and together with the random factor $\left(\mathrm{R}^{2}\right.$ conditional). Detailed information of all structural equation models is presented in Table S2. Total phosphorus was $\log$-transformed $\left(\log _{10}+1\right)$ 


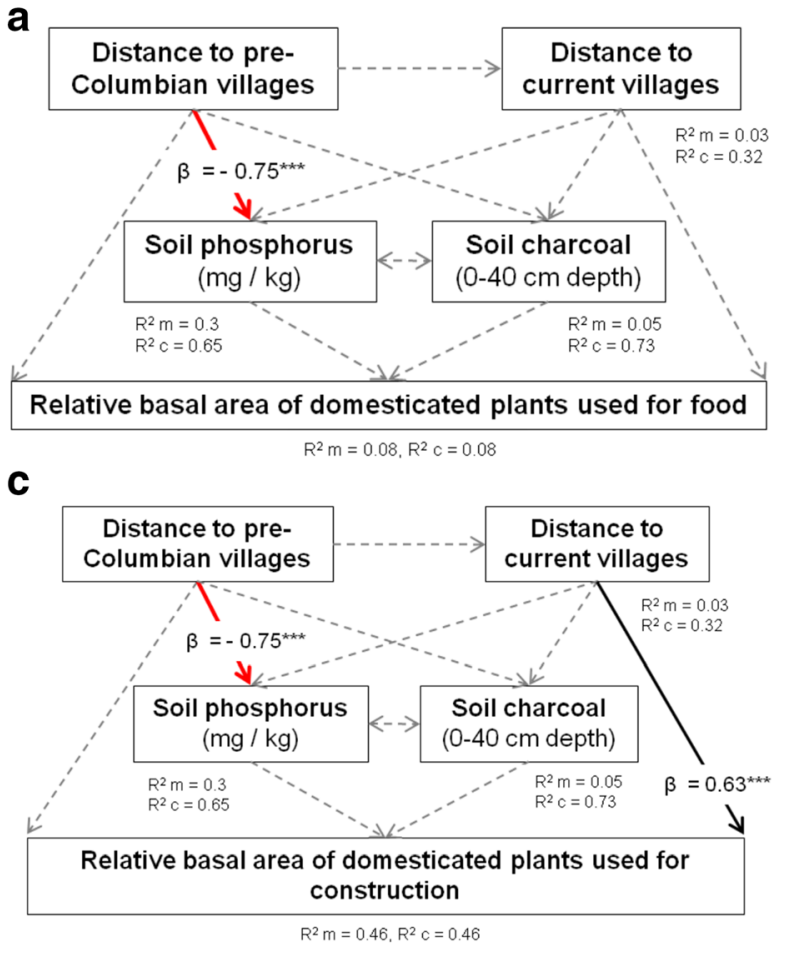

Fig. 4 The structural equation models that show the direct and indirect effects of distance to pre-Columbian and current villages on a) relative basal area of domesticated species used for food, b) relative density of domesticated species used for food, c) relative basal area of domesticated species used for construction, and d) relative density of domesticated species used for construction. Black continuous arrows show significant pathways, grey dotted arrows show non-significant pathways, and double-sided arrows show correlations. The standardized regression coefficient $(\beta)$ and

with nitrogen, phosphorus is the most limiting macronutrient in tropical forest soils (Elser et al. 2007), it determines crop production in Amazonian agroforestry systems (McGrath et al. 2000), and is considered a strong predictor of forest structure and dynamics across Amazonia (Quesada et al. 2012).

Effects of pre-Columbian and current landscape domestication on soils, fire events and vegetation

All SEM models were supported (Fisher $\mathrm{C}=2.696$, $p=0.26$ ), suggesting that they described the data with sufficient accuracy. We found a significant effect of the distance to pre-Columbian villages on soil phosphorus (Fig. 2c, and Fig. 3). Total phosphorus content was higher in forest soils closer to pre-Columbian villages and decreased with distance from forest plots to these villages (Fig. $2 c, \beta=-0.75, p<0.001$ ).

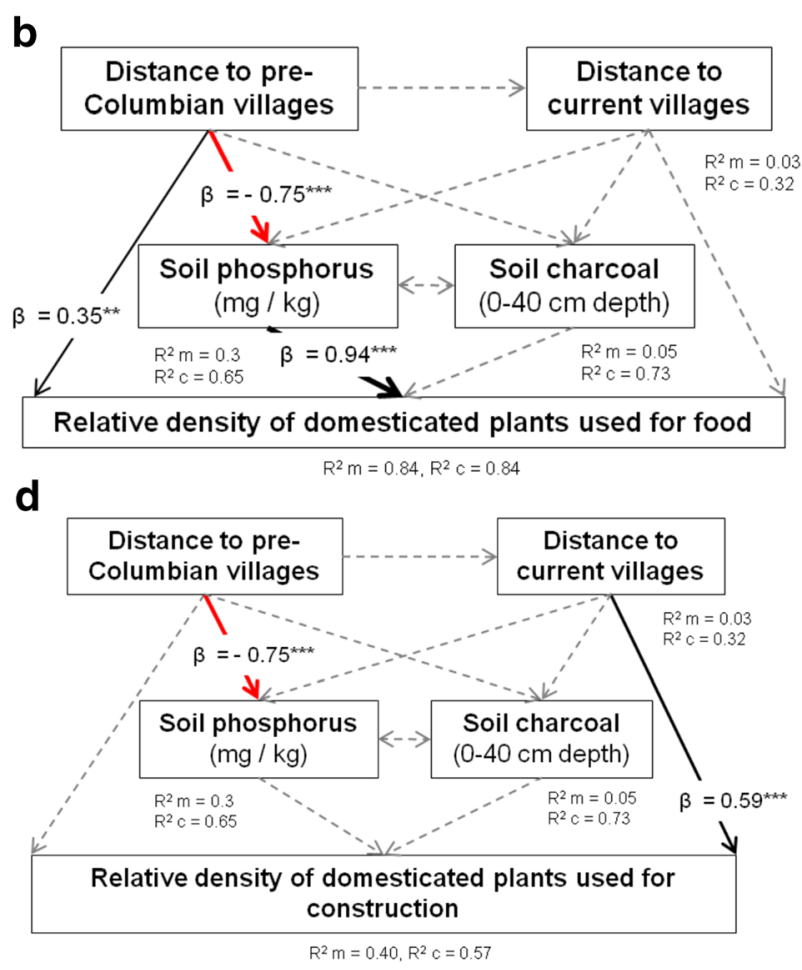

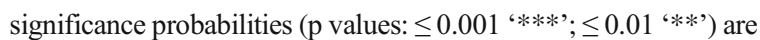
shown. $\mathrm{R}^{2}$ 's are given to indicate the total variation in a dependent variable that is explained by the combined fixed variables $\left(\mathrm{R}^{2}\right.$ marginal) and together with the random factor $\left(\mathrm{R}^{2}\right.$ conditional). Detailed information of all structural equation models is presented in Table S2. Note that all species were domesticated for food, but some are currently used for construction. Total phosphorus was log-transformed $\left(\log _{10}+1\right)$

However, total phosphorus was not related to the distance to current villages (Fig. 2 d, $p=0.596$ ). Even after removing the forest plot on ADE site from our analysis, the total amount of phosphorus in forest soils decreased significantly with the distance from plots to pre-Columbian villages (Table $\mathrm{S} 3, \beta=-0.48, p=$ $0.014)$. We did not find a significant effect of the distance to pre-Columbian villages nor of the distance to current villages on the frequency of charcoal in forest soils (Fig. 3 and Table S2), although charcoal frequency decreased slightly with the distance to current villages (Table $\mathrm{S} 2, \beta=-0.31, p=0.056$ ). Charcoal was common in all forest plots of the two river basins, suggesting that wild and/or anthropogenic fire events were widespread through time (Fig. S4). Charcoal pieces were found from 0 to $40 \mathrm{~cm}$ of soil depth, which suggests that more than one fire event occurred in the past. 


\section{a) Relative Basal Area}

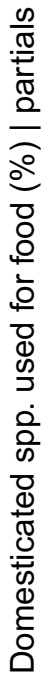

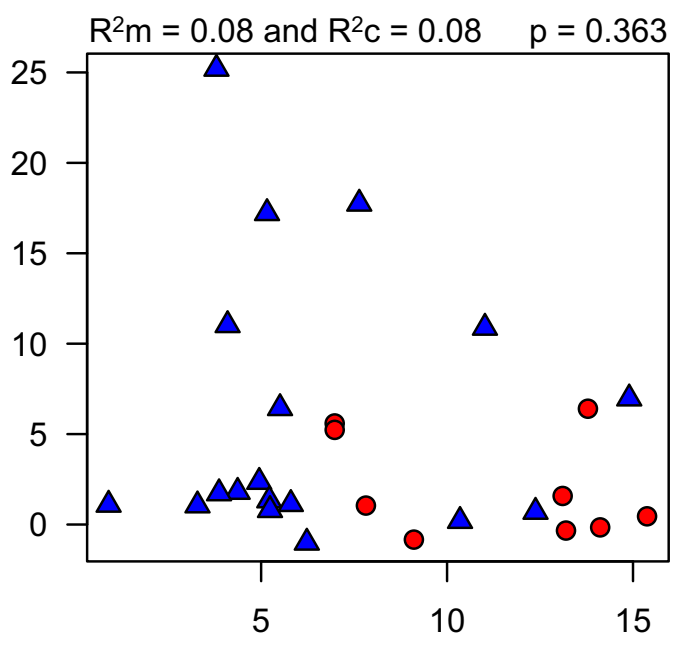

Distance to current villages $(\mathrm{km}) \mid$ partials

\section{c) Relative Basal Area}

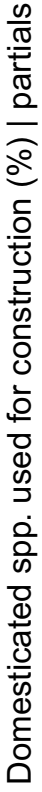

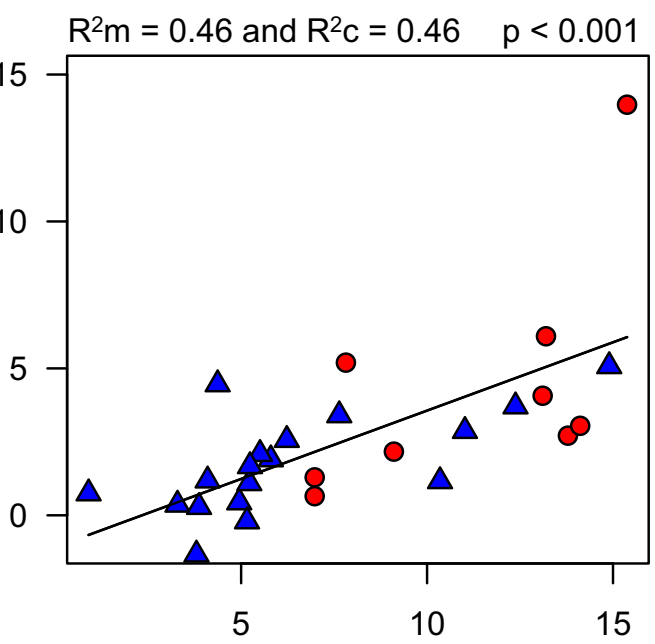

Distance to current villages $(\mathrm{km}) \mid$ partials

Fig. 5 Effects of the distance from plots to current villages on a) relative basal area of domesticated species currently used for food, b) relative density of domesticated species currently used for food, c) relative basal area of domesticated species currently used for construction, and d) relative density of domesticated species currently used for construction. Triangles are forest plots in the Tapajós River basin (18 plots) and dots are forest plots located in the Madeira River basin ( 9 plots). Regression plots were obtained from mixed-models and the fitted line indicates significant fixed-

\section{b) Relative Density}

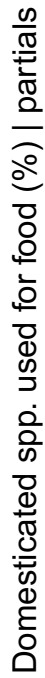

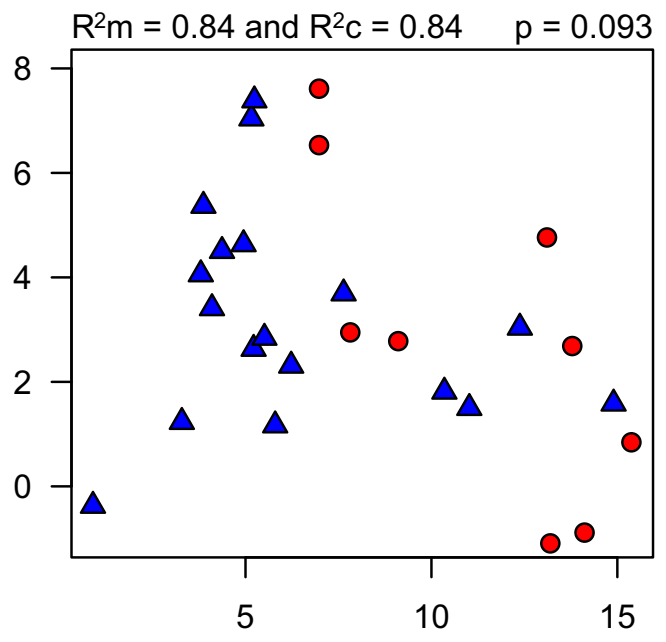

Distance to current villages $(\mathrm{km})$ | partials

\section{d) Relative Density}

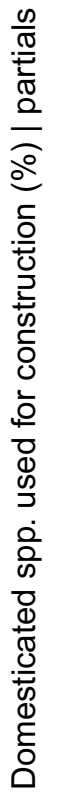

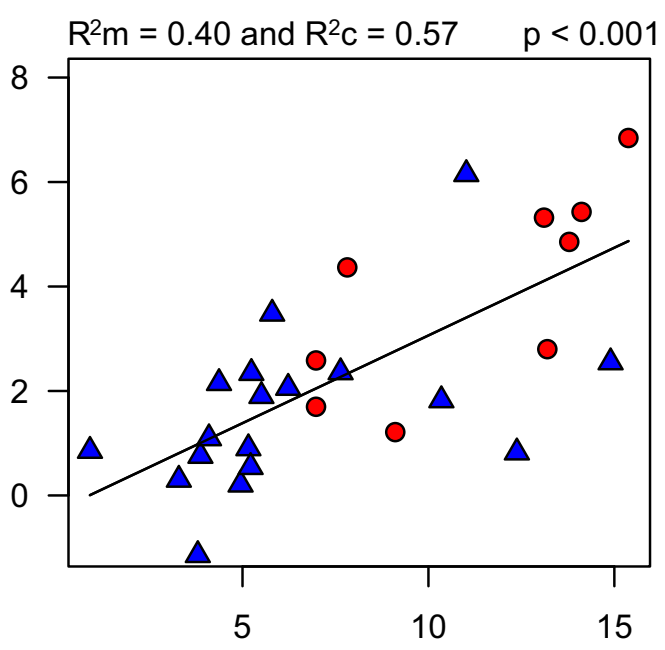

Distance to current villages $(\mathrm{km})$ | partials

effects detailed in Table S2: lme (soil variable $\sim$ distance to preColumbian villages + distance to current villages + total $\mathrm{P}+$ charcoal $+(1 \mid$ Basin $))$. Significance probabilities ( $p$ values) are shown and $\mathrm{R}^{2}$, $\mathrm{s}$ are given to indicate the total variation in a dependent variable that is explained by the combined fixed variables $\left(\mathrm{R}^{2}\right.$ marginal) and together with the random factor $\left(\mathrm{R}^{2}\right.$ conditional). Total phosphorus was $\log$-transformed $\left(\log _{10}+1\right)$. Note that all species were domesticated for food, but some are currently used for construction 
We found a direct and an indirect effect of preColumbian activities on the metrics of forest structure, total density of sub-canopy stems and total tree basal area, respectively (Fig. 3, Table S2). The distance from plots to pre-Columbian villages had a negative indirect effect $(-0.34)$, through total soil phosphorus, on the total basal area of the forests, whereas the density of subcanopy stems increased with distance from plots to preColumbian villages $(\beta=0.46, p=0.048)$.

Moreover, the relative densities and basal areas of domesticated species used for food and construction were significantly affected by total $\mathrm{P}$ in soils, and by pre-Columbian and current human activities (Fig. 4). The distance to current villages had a positive direct effect on the relative basal area and density of domesticated species currently used for construction $(\beta=0.63$ and $0.59, p<0.001$, see Fig. $5 \mathrm{c}$ and d, respectively), whereas the relative basal area and density of domesticated species used for food were not affected (Fig. 5a-b). Total $\mathrm{P}$ and the distance from forests to pre-Columbian villages had a positive and direct effect on the relative density of domesticated species used for food (Fig. 4b, $\beta=0.94$ and $0.35, p<0.001$ and 0.004 , respectively). In contrast, the distance from forest plots to pre-Columbian villages had a negative indirect effect, through total $\mathrm{P}$ on the relative density of domesticated species used for food (Fig. 4b, indirect effect $=-0.70$ ) but had no effect on species used for construction. Interestingly, the basal area of all food species is negatively correlated with the basal area of all construction species (Fig. S5), showing that they do not dominate the same forest plots.

\section{Discussion}

We detected effects of long-term domestication processes on forests and soils up to $4 \mathrm{~km}$ from pre-Columbian villages and as far as $15 \mathrm{~km}$ from current villages. In comparison with current traditional and indigenous villages located in protected areas, pre-Columbian villages were apparently smaller, but more densely distributed across landscapes in both regions. Our results suggest that pre-Columbian societies increased soil nutrients mainly calcium and phosphorus - in forest soils, resulting in the formation of $\mathrm{ADE}$ and extensive anthropogenic brown soils across the landscape, as predicted by Denevan (2004). In contrast, we did not find a strong and significant effect of current management activities on forest soils. Other studies also found that extensive land use systems were developed in many parts of Amazonia (de Souza et al. 2019) and areas of visible human influence may extend up to $5 \mathrm{~km}$ from preColumbian settlements (Heckenberger et al. 2008). By enriching soil nutrients around their villages, preColumbian societies altered environmental conditions, which favored mainly species used for food that may be nutrient-demanding (Milla et al. 2015). Nowadays, indigenous and traditional societies maintain food resources in old-growth forests near their villages, while construction materials are likely being overharvested. Overall, human legacies seem to persist in old-growth forests surrounding pre-Columbian and contemporary villages due to past soil fertilization and past and current management.

Pre-Columbian and modern spatial occupation patterns

Interfluvial areas in terra-firme forests are usually considered to have sustained low population densities due to environmental limitations, and human disturbance intensity is hypothesized to decrease exponentially up to $15 \mathrm{~km}$ from major Amazonian rivers (Bush et al. 2015). However, we found the same density of ADE sites in riverside and in interfluvial areas more than $16 \mathrm{~km}$ from perennial rivers and we did not find a decay of past human occupation as we moved away from major rivers. ADE sites were found in both riverside and interfluvial areas near small streams or depressions, up to $70 \mathrm{~km}$ from the Madeira River and $15 \mathrm{~km}$ from the Tapajós River, suggesting that the probability of finding sedentary occupation sites in interfluvial areas is higher than previously predicted, as hypothesized by (Levis et al. 2014). Other studies have shown a widespread network of pre-Columbian villages from 20 to 50 ha in the upper Xingu River basin (Heckenberger et al. 2008) and historical documents reported large indigenous villages with populations of 1000 or more across other interfluvial areas (e.g., Denevan 2014) Forest landscapes on nutrient-poor soils of the upper Negro River also hold legacies of historical landscape domestication up to $13 \mathrm{~km}$ from perennial rivers and up to $750 \mathrm{~m}$ from streams (Franco-Moraes et al. 2019). Thus, it may be too simplistic to expect that the influence of pre-Columbian people in Amazonian landscapes is mostly predicted by the distance to major rivers, since perennial and temporary rivers are abundant across the basin (Junk et al. 2011) and these small rivers or streams were likely densely occupied or intensively used by pre- 
Columbian peoples (see maps of Levis et al. 2014; McMichael et al. 2014; Palace et al. 2017). In places where small rivers were scarce, e.g., east of the lower Tapajós River, people used natural depressions and built artificial ponds (Stenborg 2016), expanding even more their territories.

Although pre-Columbian villages were found to be spatially correlated with current villages along major Amazonian rivers (McMichael et al. 2017a), they are not correlated in interfluvial areas. Current traditional societies do not occupy and manage their lands and soil properties to the same extent as past societies did (Heckenberger et al. 2008) for different reasons, such as migration to Amazonian towns (Parry et al. 2010), agricultural intensification (Jakovac et al. 2017) and land use restrictions imposed by protected areas (Amaral et al. 2013). Consequently, the domestication of forest landscapes by modern societies is more restricted to perennial river margins, especially in protected areas, while past domestication was widespread.

Effects of pre-Columbian and current landscape domestication on old-growth forests

We found strong effects of past activities on nutrients of forest soils, especially on calcium and total phosphorus, towards the core of pre-Columbian villages (ADE sites), but a weak and negative effect near current villages. Even though most studies have defined ADE and nonADE sites as discrete categories due to sharp contrasts in soil nutrients between these soils (e.g., Alho et al. 2019). Fraser et al. (2011) proposed a continuum of soil fertility from the core of ADE sites towards the adjacent soils in Central Amazonia. Schmidt et al. (2014) confirmed these observations, showing a widespread pattern of anthropogenic soil formation surrounding domestic areas in several regions of the Amazon basin. Brown soils around domestic zones have been observed in much more extensive areas, not only around ADE core areas in Central and Eastern Amazonia (Denevan 2004; Fraser et al. 2011), but also in naturally rich soils of Western Amazonia (Quintero-Vallejo et al. 2015). Overall, our results suggest that pre-Columbian peoples increased essential nutrient concentrations in Amazonian soils not only in their kitchen refuse piles and homegardens, but across a larger area than measured by previous studies (Fraser et al. 2011; Schmidt et al. 2014, Fig. 2). The extensive effect of past societies on modern forest soils is probably a result of pre-
Columbian land use systems that combined agroforestry and forest management with efficient practices of soil improvement around villages (Denevan 2004; Stahl 2015; de Souza et al. 2019).

Across the basin, the fertility of terra-firme forest soils are correlated with a natural gradient of pedogenic development that influences physical, chemical and biological processes (Quesada et al. 2010). Total phosphorus has been used to infer soil fertility, due to its correlation with pedogenic development, and to predict forest biomass and composition (Quesada et al. 2010, 2012). Soils rich in nutrients occur mainly on young terrains under western Amazonian forests, whereas old soils poor in nutrients are commonly found under Eastern and Central Amazonian forests. Soil fertility is generally higher in the Tapajós forests than in the Madeira forest, possibly due to their natural variation in soil texture, since Tapajós soils contain a much higher percentage of clay and Madeira soils a higher percentage of sand (see Table 2). Another factor that may explain these differences is the intensity of pre-Columbian activities between these regions. Because lower Tapajós forests were more densely occupied by pre-Columbian societies than middle-upper Madeira forests (see Table 1), forest soils within the lower Tapajós region may have been strongly altered by these societies. By increasing the amount of soil nutrients and $\mathrm{pH}$ in their villages and likely in the areas surrounding them (Fraser et al. 2011; Quintero-Vallejo et al. 2015), pre-Columbian societies expanded the heterogeneity of forest soils and reproduced basin-wide natural soil variation in their domesticated landscapes, creating a wide range of soil conditions to cultivate domesticated plants adapted to different levels of soil nutrients (Junqueira et al. 2016).

The basal area of old-growth forests was affected by pre-Columbian soil fertilization (Fig. 3a), confirming our initial expectation that the higher nutrient availability common in anthropogenic soils would influence forest structure. Forests on and around pre-Columbian villages had a lower sub-canopy stem density and a higher basal area than forests away from these sites. However, using indices from satellite imagery, (Palace et al. 2017) found that biomass, tree height and tree cover are lower in forests located on ADE than random forest sites within $50 \mathrm{~km}$ of ADE. Since we worked no more than $4 \mathrm{~km}$ from ADE (see also (Ferreira et al. 2019), we found small-scale differences in forest structure that may be difficult to detect using only satellite data. The forest on top of ADE had an extremely high 
value of stand basal area ( $\left.48 \mathrm{~m}^{2} / \mathrm{ha}\right)$ compared to our other study plots (Table S4) and other plots elsewhere across Amazonia (Baker et al. 2004), driven mainly by two individuals of sumaúma (Ceiba pentandra), which is an indicator of $\mathrm{ADE}$ (Clement et al. 2003). In general, forest soils with high nutrient availability promote species with high diameter increments and low wood density (Quesada et al. 2012), such as sumaúma. This broad-scale Amazonian pattern suggests that some good colonizers may persist in old-growth forests after human abandonment due to changes in soil conditions rather than due to extensive cultivation during past occupations.

Amazonian societies transformed forest landscapes around their villages by practices that not only involved direct cultivation of new seeds and seedlings, but they also selectively removed some plants (Levis et al. 2018) and certainly harvested timber products (Peres 1994; Odonne et al. 2019) The historical overharvesting of timber species could explain why the relative density and basal area of plants used for construction decreased near villages, even though the relative density of species used for food does not show the same pattern (Fig. 5). Although people use timber resources, they need to cut the trees to get timber and they may not actively replace them. In contrast, people collect food resources without the need to cut the tree and these food species have traits for fast resource acquisition that may cope better with more soil nutrients (Milla et al. 2015), and therefore persist in soils improved by pre-Columbian activities (Maezumi et al. 2018a). Ethnographic and paleoecological studies focusing on different categories of useful species may help to understand how long people have been benefiting or overharvesting plants used for food and construction surrounding their villages. For instance, pollen of useful species in lake sediments in the vicinity of archaeological sites can be used to infer human activities and enrichment of edible species during the Holocene (Maezumi et al. 2018a).

Domesticated plants were most affected by preColumbian and current landscape domestication inside habitation zones. Domesticated plants were extremely abundant in archaeological sites across Amazonia (Levis et al. 2017) and were strongly associated with anthropogenic soils in the Madeira River basin, as observed by Junqueira et al. (2010, 2017). Many domesticated species used today (e.g., Spondias mombin) were shown to be abundant in very fertile anthropogenic soils (Junqueira et al. 2016; Maezumi et al. 2018a), suggesting that only with very high nutrient levels found in ADE sites or in naturally fertile soils will we find higher densities of domesticated species across the ba$\sin$. Indeed, the density of domesticated species is higher on archaeological sites and in geological regions where fertile soils predominate, e.g., southwestern Amazonia (Levis et al. 2017). Studies in Amazonian landscapes with naturally and anthropogenically fertile soils demonstrated that domesticated species can occur over large forest areas even centuries after they were abandoned by native populations (Paz-Rivera and Putz 2009; Quintero-Vallejo et al. 2015). However, in Amazonian landscapes with naturally poor soils (Quesada et al. 2010), fully domesticated populations may only persist on $\mathrm{ADE}$ sites and even there will require continuing management (Clement 1999), but incipiently domesticated populations may flourish in anthropogenic brown soils around these sites (e.g., Caryocar villosum, see Table S1 and Alves et al. 2016).

\section{Conclusions}

We found that pre-Columbian villages were densely distributed in Amazonian forest landscapes, and that the influence of past societies has persisted in forest soils that are no longer enriched by indigenous and traditional societies. Pre-Columbian soil fertilization contributed to increase the total basal and the abundance of domesticated species used for food in old-growth forests but not for species used for construction. Currently, modern societies maintain food resources in forests near their villages, while timber resources may be overharvested.

While recent land use histories are considered an important driver of secondary forest succession (Arroyo-Rodríguez et al. 2017), long-term histories are often overlooked in old-growth forests (Dambrine et al. 2007). As our findings reveal, the analysis of land use histories across a much longer time scale is crucial to understand the heterogeneity of soils and forest composition at a landscape scale in Amazonia. Particularly, the distribution of food resources of great importance to modern societies are affected by pre-Columbian soil fertilization and may depend on current management to persist. Therefore, to guide effective conservation and management plans that aim to maintain forest resources in Amazonian landscapes, we must understand 
how they are shaped by past and current human activities.

Acknowledgements We are very grateful to all local residents for their participation in and kindness during our study. This manuscript is part of a publicly defended $\mathrm{PhD}$ thesis by the first author and was financed by the Fundação de Amparo à Pesquisa do Estado do Amazonas (FAPEAM) Universal proc. no. 3137/2012), Conselho Nacional de Desenvolvimento Científico e Tecnológico (CNPq) Universal proc. no. 473422/2012-3 and 458210/2014-5, a William John Witemberg Foundation and Research expense grant from the University of Toronto, a Mitacs Globalink Research Award, FAPEAM Newton Fund proc. no. $062.00831 / 2015$, Treub-Maatschappij, and partially funded by European Research Council project no. ERC-CoG 616179 led by José Iriarte. CRC thanks CNPq for a research fellowship (proc. no. 303477/2018-0) and CL thanks CNPq for doctoral (proc. no. 141652/2014-4 and 201573/2014-8) and postdoctoral fellowships (proc. no. 159440/2018-1). We also thank Izaias Brasil, Lilian Rebellato, Denise Schaan (in memorium), Daiana T. Alves, Iracenir dos Santos, Priscila P. Carlos, Layon O. Demarchi, ICMBio, Comflona, the Herbarium of Federal University of Western Pará (UFOPA), the Anthropology and Archaeology Department of UFOPA, the Núcleo de Apoio à Pesquisa no Pará (NAPPA - INPA/LBA), the Programa de Monitoramento da Biodiversidade (PPBio Santarém nucleus), and the Fundação Nacional do Índio (FUNAI) for field assistance; Carlos A. Quesada, Erison Gomes and Elson for soil analysis; Giselle Viana for data preparation; José Ramos, Lorena M. Rincón, Antonio C. Webber and Alberto Vicentini for botanical identification; and Bernardo M. Flores for constructive comments on this manuscript.

Open Access This article is licensed under a Creative Commons Attribution 4.0 International License, which permits use, sharing, adaptation, distribution and reproduction in any medium or format, as long as you give appropriate credit to the original author(s) and the source, provide a link to the Creative Commons licence, and indicate if changes were made. The images or other third party material in this article are included in the article's Creative Commons licence, unless indicated otherwise in a credit line to the material. If material is not included in the article's Creative Commons licence and your intended use is not permitted by statutory regulation or exceeds the permitted use, you will need to obtain permission directly from the copyright holder. To view a copy of this licence, visit http://creativecommons.org/licenses/by/4.0/.

\section{References}

Albuquerque UP, Ramos MA, de Lucena RFP, Alencar NL (2014) Methods and techniques used to collect ethnobiological data. In: Albuquerque UP, da Cunha LVF C, de Lucena RFP, Alves RRN (eds) Methods and techniques in Ethnobiology and Ethnoecology. Springer Protocols Handbooks. Humana Press, New York, pp 15-37

Alho CFBV, Samuel-Rosa A, Martins GC et al (2019) Spatial variation of carbon and nutrients stocks in Amazonian dark earth. Geoderma 337:322-332. https://doi.org/10.1016/j. geoderma.2018.09.040

Alves RP, Levis C, Clement CR (2016) Use and management of piquiá suggest in situ domestication along the lower Tapajós River, Brazilian Amazonia. Econ Bot 70:198-202. https://doi.org/10.1007/s12231-016-9340-4

Amaral S, Dal'Asta AP, Brigatti N et al (2013) Comunidades ribeirinhas como forma socioespacial de expressão urbana na Amazônia: uma tipologia para a região do Baixo Tapajós (Pará-Brasil). Rev Bras Estud Popul 30:367-399. https://doi. org/10.1590/S0102-30982013000200003

Arroyo-Rodríguez V, Melo FPL, Martínez-Ramos M et al (2017) Multiple successional pathways in human-modified tropical landscapes: new insights from forest succession, forest fragmentation and landscape ecology research: multiple successional pathways. Biol Rev 92:326-340. https://doi. org/10.1111/brv. 12231

Baker TR, Phillips OL, Malhi Y et al (2004) Variation in wood density determines spatial patterns in Amazonian forest biomass. Glob Chang Biol 10:545-562. https://doi.org/10.1111 /j.1365-2486.2004.00751.x

Balée W (2006) The research program of historical ecology. Annu Rev Anthropol 35:75-98. https://doi.org/10.1146/annurev. anthro.35.081705.123231

Balée W (2000) Antiquity of traditional ethnobiological knowledge in Amazonia: the Tupi-Guarani family and time. Ethnohistory 47:399-422. https://doi.org/10.1215 /00141801-47-2-399

Barreto C, Lima HP, Betancourt CJ (2016) Cerâmicas arqueológicas da Amazônia: rumo a uma nova síntese. IPHAN, Museu Paraense Emílio Goeldi, Belém, Pará

Berlin B (1992) Ethnobiological classification: principles of categorization of plants and animals in traditional societies. Princeton University Press, Princeton

Boivin NL, Zeder MA, Fuller DQ, Crowther A, Larson G, Erlandson JM, Denham T, Petraglia MD (2016) Ecological consequences of human niche construction: examining longterm anthropogenic shaping of global species distributions. Proc Natl Acad Sci U S A 113:6388-6396. https://doi. org/10.1073/pnas.1525200113

Breheny P, Burchett W (2017) Visualization of regression models using visreg. The R Journal 9:56. https://doi.org/10.32614 /RJ-2017-046

Bush MB, McMichael CH, Piperno DR et al (2015) Anthropogenic influence on Amazonian forests in pre-history: an ecological perspective. J Biogeogr 42:2277-2288. https://doi.org/10.1111/jbi.12638

Cámara-Leret R, Fortuna MA, Bascompte J (2019) Indigenous knowledge networks in the face of global change. Proc Natl Acad Sci U S A 201821843. https://doi.org/10.1073 /pnas. 1821843116

Cassino MF, Alves RP, Levis C et al (2019) Ethnobotany and ethnoecology applied to historical ecology. In: Albuquerque UP, de Lucena RFP, da Cunha LVF C, Alves RRN (eds) Methods and techniques in ethnobiology and ethnoecology. Springer Protocols Handbooks. Humana Press, New York, pp 187-208

Clement CR (1999) 1492 and the loss of amazonian crop genetic resources. I. the relation between domestication and human population decline. Econ Bot 53:188-202. https://doi. org/10.1007/BF02866498 
Clement CR, Cassino MF (2018) Landscape domestication and archaeology. In: Smith C (ed) Encyclopedia of global archaeology. Springer International Publishing, Cham, pp 1-8

Clement CR, Denevan WM, Heckenberger MJ, Junqueira AB, Neves EG, Teixeira WG, Woods WI (2015) The domestication of Amazonia before European conquest. Proc R Soc B 282:20150813. https://doi.org/10.1098/rspb.2015.0813

Clement CR, McCann JM, Smith NJH (2003) Agrobiodiversity in Amazonia and its relationship with Amazonian dark earths. In: Lehmann J, Kern DC, Glaser B, Woods WI (eds) Amazonian dark earths. Kluwer Academic Publishers, Dordrecht, pp 159-178

Dambrine E, Dupouey J-L, Laüt L et al (2007) Present forest biodiversity patterns in France related to former Roman agriculture. Ecology 88:1430-1439. https://doi.org/10.1890 /05-1314

Denevan WM (1992) The pristine myth: the landscape of the Americas in 1492. Ann Assoc Am Geogr 82:369-385. https://doi.org/10.1111/j.1467-8306.1992.tb01965.x

Denevan WM (2004) Semi-intensive pre-European cultivation and the origins of anthropogenic dark earths in Amazonia. In: Glaser B, Woods WI (eds) Amazonian dark earths: explorations in space and time. Springer Berlin Heidelberg, Berlin, Heidelberg, pp 135-143

Denevan WM (2014) Estimating amazonian indian numbers in 1492. J Lat Am Geogr 13:207-221. https://doi.org/10.1353 /lag.2014.0036

de Souza JG, Robinson M, Maezumi SY, Capriles J, Hoggarth JA, Lombardo U, Novello VF, Apaéstegui J, Whitney B, Urrego D, Alves DT, Rostain S, Power MJ, Mayle FE, da Cruz FW Jr, Hooghiemstra H, Iriarte J (2019) Climate change and cultural resilience in late pre-Columbian Amazonia. Nat Ecol Evol 3:1007-1017. https://doi.org/10.1038/s41559019-0924-0

de Souza JG, Schaan DP, Robinson M, Barbosa AD, Aragão LEOC, Marimon BH Jr, Marimon BS, da Silva IB, Khan SS, Nakahara FR, Iriarte J (2018) Pre-Columbian earthbuilders settled along the entire southern rim of the Amazon. Nat Commun 9:1125. https://doi.org/10.1038 /s41467-018-03510-7

Ellis EC (2015) Ecology in an anthropogenic biosphere. Ecol Monogr 85:287-331. https://doi.org/10.1890/14-2274.1

Elser JJ, Bracken MES, Cleland EE, Gruner DS, Harpole WS, Hillebrand H, Ngai JT, Seabloom EW, Shurin JB, Smith JE (2007) Global analysis of nitrogen and phosphorus limitation of primary producers in freshwater, marine and terrestrial ecosystems. Ecol Lett 10:1135-1142. https://doi. org/10.1111/j.1461-0248.2007.01113.x

Erickson CL (2008) Amazonia: the historical ecology of a domesticated landscape. In: Silverman H, Isbell WH (eds) The handbook of south American archaeology. Springer New York, New York, pp 157-183

Ferreira MJ, Levis C, Iriarte J, Clement CR (2019) Legacies of intensive management in forests around pre-columbian and modern settlements in the Madeira-Tapajós interfluve, Amazonia. Acta Bot Bras 33:212-220. https://doi. org/10.1590/0102-33062018abb0339

Figueiredo CG (2019) Regional complementarity and placemaking in the northern region of the Tapajós National Forest Reservation, Lower Amazon, Brazil. PhD Thesis, University of Toronto, Toronto, Canada
Franco-Moraes J, Baniwa AFMB, Costa FRC et al (2019) Historical landscape domestication in ancestral forests with nutrient-poor soils in northwestern Amazonia. Forest Ecol Manag 446:317-330. https://doi.org/10.1016/j. foreco.2019.04.020

Fraser J, Teixeira W, Falcão N, et al (2011) Anthropogenic soils in the Central Amazon: from categories to a continuum: Area 43:264-273. https://doi.org/10.1111/j.14754762.2011.00999.x

Grace JB, Anderson TM, Olff H, Scheiner SM (2010) On the specification of structural equation models for ecological systems. Ecol Monogr 80:67-87. https://doi.org/10.1890 /09-0464.1

Heckenberger M, Neves EG (2009) Amazonian Archaeology. Annu Rev Anthropol 38:251-266. https://doi.org/10.1146 /annurev-anthro-091908-164310

Heckenberger MJ, Russell JC, Fausto C, Toney JR, Schmidt MJ, Pereira E, Franchetto B, Kuikuro A (2008) Pre-Columbian urbanism, anthropogenic landscapes, and the future of the Amazon. Science 321:1214-1217. https://doi.org/10.1126 /science.1159769

Jakovac CC, Dutrieux LP, Siti L, Peña-Claros M, Bongers F (2017) Spatial and temporal dynamics of shifting cultivation in the middle-Amazonas river: expansion and intensification. PLoS One 12:e0181092. https://doi.org/10.1371/journal. pone.0181092

Junk WJ, Piedade MTF, Schöngart J et al (2011) A classification of major naturally-occurring Amazonian lowland wetlands. Wetlands 31:623-640. https://doi.org/10.1007/s13157-0110190-7

Junqueira AB, Levis C, Bongers F et al (2017) Response to Comment on "Persistent effects of pre-Columbian plant domestication on Amazonian forest composition". Science 358: eaan8837. https://doi.org/10.1126/science.aan8837

Junqueira AB, Shepard GH, Clement CR (2010) Secondary forests on anthropogenic soils in Brazilian Amazonia conserve agrobiodiversity. Biodivers Conserv 19:1933-1961. https://doi.org/10.1007/s10531-010-9813-1

Junqueira AB, Stomph TJ, Clement CR, Struik PC (2016) Variation in soil fertility influences cycle dynamics and crop diversity in shifting cultivation systems. Agric Ecosyst Environ 215:122-132. https://doi.org/10.1016/j. agee.2015.09.015

Kummerow C, Barnes W, Kozu T et al (1998) The tropical rainfall measuring mission (TRMM) sensor package. J Atmospheric Ocean Technol 15:9. https://doi.org/10.1175/1520-0426 (1998)015<0809:TTRMMT>2.0.CO;2

Lefcheck JS (2016) PIECEWISESEM: piecewise structural equation modelling in R for ecology, evolution, and systematics. Methods Ecol Evol 7:573-579. https://doi.org/10.1111/2041210X.12512

Levis C, Costa FRC, Bongers F, Peña-Claros M, Clement CR, Junqueira AB, Neves EG, Tamanaha EK, Figueiredo FO, Salomão RP, Castilho CV, Magnusson WE, Phillips OL, Guevara JE, Sabatier D, Molino JF, López DC, Mendoza AM, Pitman NC, Duque A, Vargas PN, Zartman CE, Vasquez R, Andrade A, Camargo JL, Feldpausch TR, Laurance SG, Laurance WF, Killeen TJ, Nascimento HE, Montero JC, Mostacedo B, Amaral IL, Guimarães Vieira IC, Brienen R, Castellanos H, Terborgh J, Carim MJ, Guimarães JR, Coelho LS, Matos FD, Wittmann F, 
Mogollón HF, Damasco G, Dávila N, García-Villacorta R, Coronado EN, Emilio T, Filho DA, Schietti J, Souza P, Targhetta N, Comiskey JA, Marimon BS, Marimon BH Jr, Neill D, Alonso A, Arroyo L, Carvalho FA, de Souza FC, Dallmeier F, Pansonato MP, Duivenvoorden JF, Fine PV, Stevenson PR, Araujo-Murakami A, Aymard CGA, Baraloto C, do Amaral DD, Engel J, Henkel TW, Maas P, Petronelli P, Revilla JD, Stropp J, Daly D, Gribel R, Paredes MR, Silveira M, Thomas-Caesar R, Baker TR, da Silva NF, Ferreira LV, Peres CA, Silman MR, Cerón C, Valverde FC, di Fiore A, Jimenez EM, Mora MC, Toledo M, Barbosa EM, Bonates LC, Arboleda NC, Farias ES, Fuentes A, Guillaumet JL, Jørgensen PM, Malhi Y, de Andrade Miranda IP, Phillips JF, Prieto A, Rudas A, Ruschel AR, Silva N, von Hildebrand P, Vos VA, Zent EL, Zent S, Cintra BB, Nascimento MT, Oliveira AA, Ramirez-Angulo H, Ramos JF, Rivas G, Schöngart J, Sierra R, Tirado M, van der Heijden G, Torre EV, Wang O, Young KR, Baider C, Cano A, Farfan-Rios W, Ferreira C, Hoffman B, Mendoza C, Mesones I, TorresLezama A, Medina MN, van Andel T, Villarroel D, Zagt R, Alexiades MN, Balslev H, Garcia-Cabrera K, Gonzales T, Hernandez L, Huamantupa-Chuquimaco I, Manzatto AG, Milliken W, Cuenca WP, Pansini S, Pauletto D, Arevalo FR, Reis NF, Sampaio AF, Giraldo LE, Sandoval EH, Gamarra LV, Vela CI, ter Steege H (2017) Persistent effects of pre-Columbian plant domestication on Amazonian forest composition. Science 355:925-931. https://doi.org/10.1126 /science.aal0157

Levis C, Flores BM, Moreira PA et al (2018) How people domesticated Amazonian forests. Front Ecol Evol 5:171. https://doi. org/10.3389/fevo.2017.00171

Levis C, Silva MS, Silva MA et al (2014) What do we know about the distribution of Amazonian Dark Earth along tributary rivers in Central Amazonia? In: Stéphen R (ed) Antes de Orellana. Actas del 3 er Encuentro Internacional de Arqueología Amazónica. Instituto Francés de Estudios Andinos, Lima, Peru, pp 305-312

Levis C, de Souza PF, Schietti J, Emilio T, Pinto JL, Clement CR, Costa FR (2012) Historical human footprint on modern tree species composition in the Purus-Madeira interfluve, Central Amazonia. PLoS One 7:e48559. https://doi.org/10.1371 /journal.pone.0048559

Maezumi SY, Alves D, Robinson M, de Souza JG, Levis C, Barnett RL, Almeida de Oliveira E, Urrego D, Schaan D, Iriarte $\mathrm{J}$ (2018a) The legacy of 4,500 years of polyculture agroforestry in the eastern Amazon. Nat Plants 4:540-547. https://doi.org/10.1038/s41477-018-0205-y

Maezumi SY, Whitney BS, Mayle FE et al (2018b) Reassessing climate and pre-Columbian drivers of paleofire activity in the Bolivian Amazon. Quatern Int 488:81-94. https://doi. org/10.1016/j.quaint.2017.11.053

Mayle FE, Iriarte J (2014) Integrated palaeoecology and archaeology - a powerful approach for understanding pre-Columbian Amazonia. J Archaeol Sci 51:54-64. https://doi.org/10.1016 j.j.jas.2012.08.038

Mayle FE, Power MJ (2008) Impact of a drier early-midHolocene climate upon Amazonian forests. Phil Trans R Soc B 363:1829-1838. https://doi.org/10.1098 /rstb.2007.0019

McGrath DA, Duryea ML, Comerford NB, Cropper WP (2000) Nitrogen and phosphorus cycling in an Amazonian agroforest eight years following forest conversion. Ecol Appl 10:1633-1647. https://doi.org/10.1890/1051-0761 (2000)010[1633:NAPCIA]2.0.CO;2

McMichael CH, Feeley KJ, Dick CW et al (2017a) Comment on "Persistent effects of pre-Columbian plant domestication on Amazonian forest composition". Science 358:eaan8347. https://doi.org/10.1126/science.aan8347

McMichael CH, Palace MW, Bush MB, Braswell B, Hagen S, Neves EG, Silman MR, Tamanaha EK, Czarnecki C (2014) Predicting pre-Columbian anthropogenic soils in Amazonia. Proc R Soc B 281:20132475. https://doi.org/10.1098 /rspb.2013.2475

McMichael CH, Piperno DR, Bush MB, Silman MR, Zimmerman AR, Raczka MF, Lobato LC (2012) Sparse pre-Columbian human habitation in Western Amazonia. Science 336:14291431. https://doi.org/10.1126/science.1219982

McMichael CNH, Matthews-Bird F, Farfan-Rios W, Feeley KJ (2017b) Ancient human disturbances may be skewing our understanding of Amazonian forests. Proc Natl Acad Sci U S A 114:522-527. https://doi.org/10.1073/pnas.1614577114

Milla R, Osborne CP, Turcotte MM, Violle C (2015) Plant domestication through an ecological lens. Trends Ecol Evol 30: 463-469. https://doi.org/10.1016/j.tree.2015.06.006

Miller ET (1992) Adaptação agrícola pré-histórica no alto rio Madeira. In: Meggers BJ (ed) Prehistoria Sudamericana: nuevas perspectivas. Taraxacum, Washington, pp 219-232

Moraes CDP, Neves EG (2012) O ano 1000: Adensamento populacional, interação e conflito na Amazônia Central. Amazônica 4:122-148. https://doi.org/10.18542/amazonica. v4i1.884

Neves EG, Petersen JB, Bartone RN, Silva CAD (2003) Historical and socio-cultural origins of Amazonian dark earth. In: Lehmann J, Kern DC, Glaser B, Woods WI (eds) Amazonian dark earths. Kluwer Academic Publishers, Dordrecht, pp 29-50

Odonne G, Bel M, Burst M et al (2019) Long-term influence of early human occupations on current forests of the Guiana shield. Ecology 100. https://doi.org/10.1002/ecy.2806

Palace MW, McMichael CNH, Braswell BH et al (2017) Ancient Amazonian populations left lasting impacts on forest structure. Ecosphere 8:e02035. https://doi.org/10.1002/ecs2.2035

Parry L, Peres CA, Day B, Amaral S (2010) Rural-urban migration brings conservation threats and opportunities to Amazonian watersheds: rural-urban migration in Amazonia. Conserv Lett 3:251-259. https://doi.org/10.1111/j.1755-263 X.2010.00106.X

Paz-Rivera C, Putz FE (2009) Anthropogenic soils and tree distributions in a lowland Forest in Bolivia. Biotropica 41:665675. https://doi.org/10.1111/j.1744-7429.2009.00521.x

Peggion EA (2006) Ritual e vida cotidiana no sul do Amazonas: os Tenharim do rio Marmelos. Perspectivas 29:149-168

Peres CA (1994) Indigenous reserves and nature conservation in Amazonian forests. Conserv Biol 8:586-588. https://doi. org/10.1046/j.1523-1739.1994.08020586.x

Pinheiro J, Bates D, DebRoy S, Sarkar D (2018) Nlme: linear and nonlinear mixed effects models. $\mathrm{R}$ package version 3:1-137

Piperno DR, McMichael C, Bush MB (2015) Amazonia and the Anthropocene: What was the spatial extent and intensity of human landscape modification in the Amazon Basin at the end of prehistory? The Holocene 25(10):1588-1597. https://oi.org/10.1177/0959683615588374 
Pleysier J, Juo A (1980) A single-extraction method using silverthiourea for measuring exchangeable cations and effective CEC in soils with variable charges. Soil Sci 129:205-211

Politis G (2009) NUKAK: Ethnoarchaeology of an Amazonian people. Left Coast Press, Walnut Creek

Quesada CA, Lloyd J, Schwarz M et al (2010) Variations in chemical and physical properties of Amazon forest soils in relation to their genesis. Biogeosciences 7:1515-1541. https://doi.org/10.5194/bg-7-1515-2010

Quesada CA, Phillips OL, Schwarz M et al (2012) Basin-wide variations in Amazon forest structure and function are mediated by both soils and climate. Biogeosciences 9:2203-2246. https://doi.org/10.5194/bg-9-2203-2012

Quintero-Vallejo E, Klomberg Y, Bongers F et al (2015) Amazonian dark earth shapes the understory plant community in a Bolivian forest. Biotropica 47:152-161. https://doi. org/10.1111/btp.12193

Development Core Team R (2018) R: a language and environment for statistical computing. R Foundation for Statistical Computing, Vienna

Rival L (2007) Domesticating the landscape, producing crops and reproducing Society in Amazonia. In: Parkin DJ, Ulijaszek SJ (eds) Holistic anthropology: emergence and convergence. Berghahn Books, New York, pp 72-90

Ross NJ (2011) Modern tree species composition reflects ancient Maya "forest gardens" in Northwest Belize. Ecol Appl 21: 75-84. https://doi.org/10.1890/09-0662.1

Schaan D, Figueiredo CG, Alves DT, Stenborg P (2015) Selva cultivada: desenvolvimento socio-econômico e mudanças ambientais na amazônia pré-Colombiana. IPHAN, Brasília

Schmidt MJ, Rapp Py-Daniel A, de Paula MC et al (2014) Dark earths and the human built landscape in Amazonia: a widespread pattern of anthrosol formation. J Archaeol Sci 42:152165. https://doi.org/10.1016/j.jas.2013.11.002

Schroth G, Coutinho P, Moraes VHF, Albernaz AL (2003) Rubber agroforests at the Tapajós river, Brazilian Amazonenvironmentally benign land use systems in an old forest frontier region. Agric Ecosyst Environ 97:151-165. https://doi.org/10.1016/S0167-8809(03)00116-6
Stahl PW (2015) Interpreting interfluvial landscape transformations in the pre-Columbian Amazon. Holocene 25:15981603. https://doi.org/10.1177/0959683615588372

Stenborg P (2016) Beyond waters: archaeology and environmental history of the Amazonian inland, Gothenburg. University of Gothenburg, Gothenburg

Stenborg P, Schaan DP, Figueiredo CG (2018) Contours of the past: LiDAR data expands the limits of late pre-Columbian human settlement in the Santarém region, lower Amazon. J Field Archaeol 43:44-57. https://doi.org/10.1080 /00934690.2017.1417198

Tang Y, Horikoshi M, Li W (2016) Ggfortify: unified Interface to visualize statistical results of popular $\mathrm{R}$ packages. The $\mathrm{R}$ journal 8:474. https://doi.org/10.32614/RJ-2016-060

Teixeira PC, Donagemma GK, Fontana A, Teixeira WG (2017) Manual de Métodos de Análise de Solo, 3rd edn. Embrapa, Brasília, DF

Trant AJ, Nijland W, Hoffman KM, Mathews DL, McLaren D, Nelson TA, Starzomski BM (2016) Intertidal resource use over millennia enhances forest productivity. Nat Commun 7: 12491. https://doi.org/10.1038/ncomms12491

van Gemerden BS, Olff H, Parren MPE, Bongers F (2003) The pristine rain forest? Remnants of historical human impacts on current tree species composition and diversity: the pristine rain forest? J Biogeogr 30:1381-1390. https://doi. org/10.1046/j.1365-2699.2003.00937.x

Walkley A, Black IA (1934) An examination of the Degtjareff method for determining soil organic matter, and a proposed modification of the chromic acid titration method. Soil Sci 37:29-38. https://doi.org/10.1097/00010694-19340100000003

Woods WI, Denevan WM, Rebellato L (2013) How many years do you get for couterfeitting a paradise? In: Hayes SE, Wingard JD (eds) Soils, climate and society archaeological investigations in ancient America. University Press of Colorado, Denver, pp 1-20

Publisher's note Springer Nature remains neutral with regard to jurisdictional claims in published maps and institutional affiliations. 